\title{
Ice-dynamic projections of the Greenland ice sheet in response to atmospheric and oceanic warming
}

\author{
J. J. Fürst ${ }^{1, *}$, H. Goelzer ${ }^{1}$, and P. Huybrechts ${ }^{1}$ \\ ${ }^{1}$ Earth System Science \& Departement Geografie, Vrije Universiteit Brussel, Brussels, Belgium \\ * Invited contribution by J. J. Fürst, recipient of the EGU Outstanding Student Poster Award 2011. \\ Correspondence to: J. J. Fürst (johannes.fuerst@vub.ac.be)
}

Received: 10 June 2014 - Published in The Cryosphere Discuss.: 16 July 2014

Revised: 5 March 2015 - Accepted: 16 April 2015 - Published: 20 May 2015

\begin{abstract}
Continuing global warming will have a strong impact on the Greenland ice sheet in the coming centuries. During the last decade (2000-2010), both increased melt-water runoff and enhanced ice discharge from calving glaciers have contributed $0.6 \pm 0.1 \mathrm{~mm} \mathrm{yr}^{-1}$ to global sea-level rise, with a relative contribution of 60 and $40 \%$ respectively. Here we use a higher-order ice flow model, spun up to present day, to simulate future ice volume changes driven by both atmospheric and oceanic temperature changes. For these projections, the flow model accounts for runoff-induced basal lubrication and ocean warming-induced discharge increase at the marine margins. For a suite of 10 atmosphere and ocean general circulation models and four representative concentration pathway scenarios, the projected sea-level rise between 2000 and 2100 lies in the range of +1.4 to $+16.6 \mathrm{~cm}$. For two low emission scenarios, the projections are conducted up to 2300. Ice loss rates are found to abate for the most favourable scenario where the warming peaks in this century, allowing the ice sheet to maintain a geometry close to the presentday state. For the other moderate scenario, loss rates remain at a constant level over 300 years. In any scenario, volume loss is predominantly caused by increased surface melting as the contribution from enhanced ice discharge decreases over time and is self-limited by thinning and retreat of the marine margin, reducing the ice-ocean contact area. As confirmed by other studies, we find that the effect of enhanced basal lubrication on the volume evolution is negligible on centennial timescales. Our projections show that the observed rates of volume change over the last decades cannot simply be extrapolated over the 21 st century on account of a different balance of processes causing ice loss over time. Our results also indicate that the largest source of uncertainty arises from the
\end{abstract}

surface mass balance and the underlying climate change projections, not from ice dynamics.

\section{Introduction}

Volume changes of the Greenland ice sheet result from a balance between ice accumulation on its surface and ice loss around its margin by both meltwater runoff and ice discharge into the surrounding ocean. In the 30 -year period prior to 1990, the ice sheet has been in a virtual balance with the prevailing climate but has since been losing mass at an increasing rate (Rignot et al., 2011; Zwally et al., 2011; Shepherd et al., 2012; Sasgen et al., 2012). Almost half of this recent mass loss is attributed to increased ice discharge at the marine margins (van den Broeke et al., 2009; Shepherd et al., 2012; Sasgen et al., 2012; Vaughan et al., 2013), with a tendency towards relatively more surface melting since 2005 (Csatho et al., 2014; Enderlin et al., 2014). During the period 1972 to 1995, glacier terminus positions and ice flow were rather stable around Greenland (Moon and Joughin, 2008; Howat and Eddy, 2011; Bevan et al., 2012). Over the last decade, however, ice-sheet-wide surface velocity observations reveal complex spatial and temporal changes with accelerated glacier flow in the northwest, more variability in the southeast and relatively steady flow elsewhere (Moon et al., 2012, 2014; Carr et al., 2013).

A prominent example of recent dynamic changes of outlet glaciers in west Greenland is Jakobshavn Isbræ. Starting in 1998, its frontal zone sped up from about 6 to $12 \mathrm{~km} \mathrm{yr}^{-1}$ within 5 years (Joughin et al., 2004, 2008c). One hypothesis links the acceleration to a successive loss of buttressing 
on the grounded ice as the floating ice tongue destabilised and collapsed. Another hypothesis points to a speed-up initiated by a weakening of the ice at the lateral glacier margins (van der Veen et al., 2011). In any case, the initiation of the glacier acceleration and retreat coincides with an intrusion of warm Atlantic Water into Disco Bay that likely entered the local fjord systems (Holland et al., 2008).

In southeast Greenland, speed-up and retreat peaked in 2005 for Helheim and Kangerlussuaq glaciers, which are both located at the end of $\sim 80 \mathrm{~km}$ long fjords. Before 2005, the speed and retreat pattern of both glaciers were not synchronous (Stearns and Hamilton, 2007; Joughin et al., 2008b). While Helheim showed a continuous acceleration starting in 2002 with a cumulative retreat of the ice front of $8 \mathrm{~km}$ by 2005, Kangerlussuaq exhibited an abrupt retreat and acceleration between 2004 and 2005. Yet for both glaciers, the acceleration events were temporary and glacier speeds dropped again to the pre-speed-up level (Bevan et al., 2012). There is evidence that relatively warm waters temporarily reached the Greenland coast in this region in 2003 and 2004 (Murray et al., 2010). Similar temperature anomalies were not observed thereafter, coinciding with the dynamic re-stabilisation of outlet glaciers.

At the northern margin of the Greenland ice sheet, Petermann Glacier recently lost a major part of its $80 \mathrm{~km}$ long floating tongue. On 4 August 2010, about one-fifth of the ice tongue broke off and drifted out of the fjord into Nares Strait (Falkner et al., 2011). In line with the above speed-up examples, this breakup event was also preceded by ocean warming in the $100 \mathrm{~m}$ above the $300 \mathrm{~m}$ deep sill at the southern end of Nares Strait (Münchow et al., 2011).

Warm and saline waters of tropical origin are in fact found at intermediate depth beyond the continental shelf break all around Greenland. There is evidence that these waters can flow over the sills of individual fjord systems around Greenland (Straneo et al., 2010, 2012; Straneo and Heimbach, 2013; Inall et al., 2014). Warming of deep fjord water can intensify submarine melt below an existing ice shelf or mélange cover (Motyka et al., 2011), or directly at the calving front (Rignot et al., 2010). The ice mélange is thought to play a role in the mechanical backstress it applies on the calving face. Thinning in the frontal zone, in turn, reduces the buttressing on the upstream glacier trunk and alters the local stress regime in favour of glacier acceleration (Nick et al., 2009). This provides a physical explanation of the simultaneous occurrence of recent glacier accelerations with warm waters reaching the respective shorelines.

Apart from the oceanic influence, the ice flow towards the margin is also affected by seasonal meltwater production at the surface that finds its way to the ice-sheet base (e.g. Schoof, 2010). Observations on both ice velocity and local runoff at various positions along the western flank of the Greenland ice sheet show distinct speed-up events during the melt season (Zwally et al., 2002; van de Wal et al., 2008; Bartholomew et al., 2011; Sundal et al., 2011). Though ob- servations and simulations indicate that the effect might be small on annual timescales (Shannon et al., 2013; Tedstone et al., 2014), basal lubrication is hypothesised to enhance ice flow towards the marine margin and thereby influence ice discharge.

While ice discharge changes explain about $40 \%$ of the recent ice loss on Greenland, the remainder is attributed to a decreasing surface mass balance (Sasgen et al., 2012). Most direct observations of the surface mass balance (SMB) components have local and at most regional character and are limited to the last decade (van den Broeke et al., 2011). Therefore, they are too short and not representative to directly infer ice-sheet-wide trends. Yet SMB modelling has improved with the availability of validation data. Regional climate models are now capable of producing a physically based, ice-sheet-wide SMB estimate (Ettema et al., 2009; Fettweis et al., 2011; Vernon et al., 2013). SMB model results show that the 5 years with highest annual meltwater runoff since 1870 fall into the period after 1998 (Hanna et al., 2011). This concentrated occurrence of years with peak runoff exemplifies the general increase in runoff or decrease in SMB since the late 1990s (Ettema et al., 2009). In addition, the melt area has continuously increased, and melt extents since 2000 are on average twice as large as in the early 1980s (Fettweis et al., 2011).

For ice loss on Greenland over the next few centuries, a major contribution is expected from a decreasing SMB, or more precisely an increase in surface meltwater runoff (Church et al., 2013). By now, the modelling community has managed to improve regional climate models (RCMs) to the point that they reproduce past and present changes in various components of the SMB rather well (Vernon et al., 2013). Owing to a shortage in the observational coverage, the largest source of model uncertainty remains in the treatment and quantification of meltwater percolation and refreezing within the snowpack. Computational constraints typically limit RCM applications on ice-sheet-wide scales to coarsegrid resolution (often beyond $10 \mathrm{~km}$ ). Yet it is within a narrow band of several tens of kilometres around the ice-sheet margin that the largest SMB changes are expected under atmospheric warming. Assuming small perturbations, RCM simulations often use a fixed ice-sheet geometry, thus neglecting feedbacks between surface elevation and SMB as well as between surface albedo and ice margin retreat. Under strong future warming, thinning and the resulting elevation changes at margins may become large enough that these simplifying assumptions no longer hold. For small perturbations, a downsampling procedure for RCM SMB fields could be used to correct the RCM SMB a posteriori for a changing geometry (Franco et al., 2012). In large-scale ice-flow models however, the SMB component often relies on temperature-index approaches for surface melting (Huybrechts, 2002; Robinson et al., 2011; Greve et al., 2011). Though such approaches rely on parameterisations of individual SMB components, ice volume projections can then 
account for the feedback between changes in ice sheet geometry and extent and consequent changes in SMB.

Here we include additional ice-dynamical processes in a thermomechanically coupled, three-dimensional ice flow model (Huybrechts and de Wolde, 1999) with the aim of better assessing the impact of ice dynamics on ice volume projections. These projections are driven by the four representative concentration pathways (RCPs), specified by Moss et al. (2010) and used for the IPCC's Fifth Assessment Report (AR5; IPCC, 2013). The ice dynamic model component includes parameterisations for ocean warminginduced discharge increase and runoff-induced basal lubrication (Sect. 2). To sample the range of climate sensitivities, a selection of 10 atmosphere and ocean general circulation models (AOGCMs) from the CMIP5 data set (Taylor et al., 2012 ) is used. From this climatic input, both atmospheric and oceanic forcing is applied as anomalies to drive the ice-sheet model (Sect. 3). We first evaluate the model against observations from the recent past (Sect. 4) and then explore the influence of changes in ice discharge and in SMB on the contribution of the Greenland ice sheet to future sea-level rise (Sect. 5).

\section{Model description and spin-up}

\subsection{The ice-sheet model}

The three-dimensional, thermomechanically coupled icesheet model comprises three main components that respectively describe the mass balance at the upper and lower icesheet boundaries, the ice sheet dynamics and thermodynamics, and the isostatic adjustment of the Earth lithosphere (Huybrechts and de Wolde, 1999; Huybrechts, 2002; Fürst et al., 2011).

\subsubsection{Ice-sheet dynamics}

The simulated ice flow arises as a viscous response of the material to gravitational forcing. Using a higher-order approximation to the Stokes momentum balance, the model accounts for effects from both vertical shear stresses and horizontal gradients in membrane stresses (Fürst et al., 2011). More specifically, the model adopts a multilayer longitudinal stresses approximation of the force balance, abbreviated as LMLa in Hindmarsh (2004). This ice-dynamical core allows for a more realistic inland transmission of perturbations at the ice-sheet margin (Fürst et al., 2013). The model is run on a $5 \mathrm{~km}$ uniform-resolution grid in the horizontal plane and uses 30 non-equidistant layers in the vertical. The vertical grid spacing is refined towards the bottom where vertical shearing is concentrated. The flow component of the ice-sheet model also accounts for the direct effect of ocean warming on ice discharge and for runoff-induced lubrication. Both effects are parameterised and presented in the following sections.

\subsubsection{Surface mass balance}

The SMB model comprises snow accumulation, meltwater runoff and meltwater retention in the snowpack. The background field for surface accumulation is based on the Bales et al. (2009) accumulation map for the period 1950-2000. For the ablation component, the melt and runoff model relies on the widely used positive degree-day runoff/retention approach (Janssens and Huybrechts, 2000; Gregory and Huybrechts, 2006). This approach first determines the positive degree-day sum from monthly air temperature input, assuming a statistical variability of daily near-surface temperatures around the monthly mean (with a standard deviation of $4.2^{\circ} \mathrm{C}$ ). Melt rates are then determined with different degreeday factors for snow and ice. Their values are determined by tuning during the model spin-up (Sect. 2.4 and Table 1). Surface melt is first stored as capillary water until the snowpack becomes saturated and runoff occurs. In the snowpack model, formation of superimposed ice occurs when watersaturated snow survives above the impermeable ice layer until the end of the season, and subsequently refreezes. The SMB model relies on a parameterisation of the surface temperature calibrated for the period 1960-1990 (Huybrechts and de Wolde, 1999). The model is forced by monthly surface air temperature and annual precipitation anomalies relative to the 1960-1990 mean. For the period 1958-2010, the positive degree-day runoff/retention approach has been compared to RACMO2.1/GR, a physical snow model coupled to a high-resolution model for atmosphere dynamics (Hanna et al., 2011). Both approaches for SMB agree well in terms of interannual variability ( $R^{2}$ coefficients of determination of 0.79 for SMB, 0.84 for precipitation, and 0.75 for runoff).

\subsubsection{Input data}

Geometric input has been updated from the Bamber et al. (2013) data set with slight adjustments for our specific model requirements (Goelzer et al., 2013). A geoid correction is applied to reference the data set to mean sea level, which is subsequently re-projected and interpolated from the original $1 \mathrm{~km}$ grid to the ice-sheet model grid. The geothermal heat flux is inferred from seismic data (Shapiro and Ritzwoller, 2004). The values were adjusted with Gaussian functions at the deep ice core sites (NEEM, GRIP, NGRIP, Dye3 and Camp Century), assuming a radius of $100 \mathrm{~km}$ to gradually blend in the difference with the background field, such that the model reproduces observed basal temperatures (Pattyn, 2010).

\subsection{Effect of surface runoff on basal lubrication}

Observations of ice velocities show seasonal speed-up in the summer melt period (Zwally et al., 2002; Bartholomew et al., 2011; Sundal et al., 2011). Surface runoff generally finds 
a way into the ice body through moulins and the water is assumed to reach the bed near the ice-sheet margin. The rate of basal meltwater discharge determines the two-fold character of the subglacial drainage system, which in turn controls lubrication and its effect on the sliding velocity (e.g. Schoof, 2010). Observational studies often report on successive distinct speed-up events during the melt season (Zwally et al., 2002; Bartholomew et al., 2011; Andrews et al., 2014; Tedstone et al., 2014). For our model application, however, the interest is on their integrated effect over 1 year. Sundal et al. (2011) find that mean summer speed-up is positively correlated with daily runoff, as long as runoff rates do not exceed a certain threshold. Above this threshold, average speed-up is somewhat reduced as exemplified in the two-fold character of basal drainage. The annual runoff will strongly depend on the number of days for which this threshold is exceeded. Therefore, we assume a relation between the annual surface runoff and the annual increase in sliding relative to the winter reference. In this way, the speed-up parameterisation will not distinguish between years of comparable annual runoff, caused primarily by moderate but constant melting during the entire summer season or by individual high melt peaks. In the ice flow model, the Weertman sliding relation is therefore extended with a multiplier $S_{\mathrm{BL}}$ that depends on the annual rate of basal meltwater discharge.

$v_{\mathrm{b}}=S_{\mathrm{BL}} \frac{A_{\mathrm{S}}}{H} \tau_{\mathrm{b}}^{3}$

Here sliding velocities are denoted with $v_{\mathrm{b}}$, basal drag with $\tau_{\mathrm{b}}$ (the sum of all resistive forces), the sliding factor with $A_{\mathrm{S}}$ and the ice thickness with $H$. In this parameterisation, the basal meltwater discharge rate is assumed equal to the local surface runoff $R$, whilst neglecting contributions from basal melting or meltwater routing beneath the ice sheet. The chosen $5 \mathrm{~km}$ spacing supports the concept that surface meltwater reaches the bed within the distance of one grid cell. Theoretical work on subglacial drainage systems indicates a speed-up peak for a specific rate of basal water discharge (Schoof, 2010). Above this discharge rate, a channelised basal drainage system develops, which is associated with lower relative speed-up values. In the absence of local runoff, no lubrication effect is simulated $\left(S_{\mathrm{BL}}=1\right)$. Informed by the best-fit parameterisation in Shannon et al. (2013), we apply a Poisson-like functional dependence (Fig. 1) between relative speed-up and runoff.

$S_{\mathrm{BL}}=1+c R^{a} \cdot \exp (-b R)$

In this notation, the unknown parameters $a, b$ and $c$ are assumed positive. Within a comprehensive uncertainty study on the chosen functional dependence (covering a large range for our three parameters), Shannon et al. (2013) find that the lubrication effect is of secondary importance in terms of the centennial ice volume evolution. Therefore, only one set of parameters is used for the projections here.

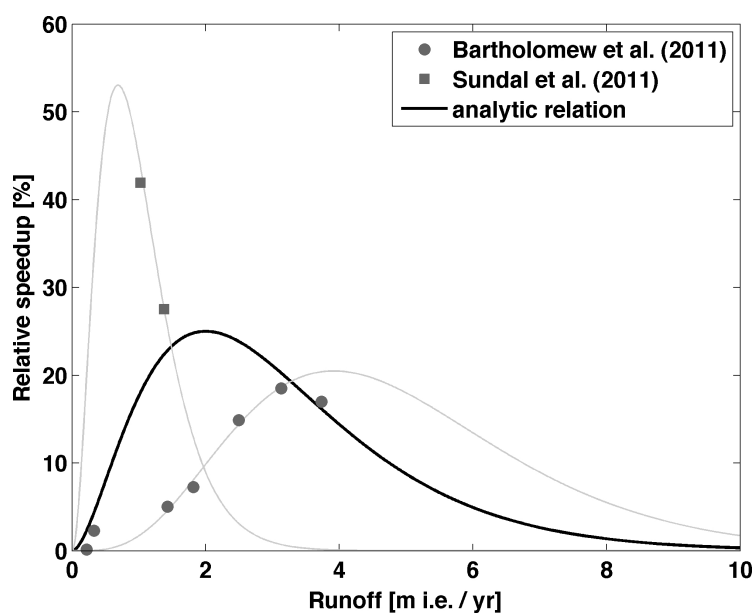

Figure 1. Functional dependence of relative annual speed-up on local runoff. Dark grey symbols indicate either direct field observations (Bartholomew et al., 2011) or observed speed-up combined with output from a SMB model (Sundal et al., 2011). Observational data originate from Russell Glacier, east of Kangerlussuaq. The parameterisation considers a functional dependence (black line) that is a compromise among all observations. Grey thin lines indicate a best fit to the respective data sets.

The three unknown parameters are determined using observational data on annual velocity increase and runoff at two locations along the western flank of the Greenland ice sheet (Fig. 1). The first location is east of Kangerlussuaq and upstream of Russell Glacier, often referred to as the K-transect (van de Wal et al., 2008; Shepherd et al., 2009; Bartholomew et al., 2010, 2011). Here a consistent picture emerges with annual mean velocities of up to $20 \%$ above the winter background for runoff rates below $3.5 \mathrm{~m}$ ice equivalent $\mathrm{yr}^{-1}$. For the Russell Glacier transect, Bartholomew et al. (2011) find the highest velocities for observed runoff rates above $3 \mathrm{~m} \mathrm{yr}^{-1}$. In the larger vicinity of the K-transect, Sundal et al. (2011) link the speed-up of several glaciers to runoff extracted from a monthly degree-day surface meltwater runoff/retention model. Their findings indicate a velocity peak for an annual runoff below $1 \mathrm{~m}$. This difference between observed and modelled critical runoff rates is considered in our functional dependence. For our simulated ice-sheet geometry, our mass balance model gives annual runoff rates of up to $4 \mathrm{~m} \mathrm{yr}^{-1}$ near the K-transect. Due to a faster inland decrease in modelled runoff, as compared to observations, upstream speed-up would be underestimated. Taking this into account, the following parameter values are chosen: $a=1.8$, $b=0.9 \mathrm{yr} \mathrm{m}^{-1}$ and $c=0.43$. For these parameters, the maximum annual velocity lies $25 \%$ above the winter reference for an annual runoff rate of $2 \mathrm{~m} \mathrm{yr}^{-1}$ (Fig. 1). In this way, the presented parameterisation might be affected by the observational bias towards the western flank of the Greenland ice sheet. 


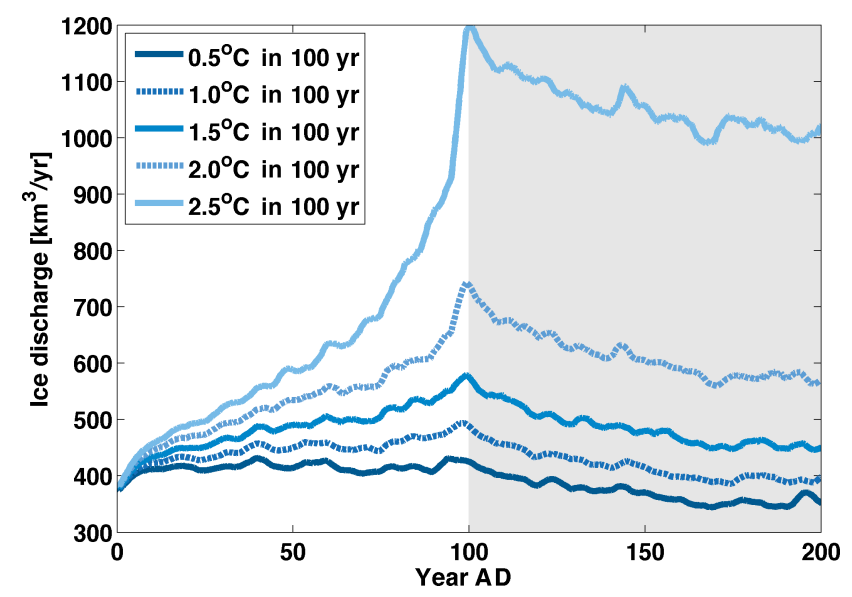

Figure 2. Ice discharge response to a linear increase in ocean temperature. The atmospheric forcing is unchanged and based on the SMB of one climate model (i.e. 2005 MPI-ESM-LR). Ocean temperature increase is linear for 100 years and is then kept at the same level.

However, the magnitude of the runoff rate causing maximum speed-up agrees with theoretical estimates using an idealised ice-sheet geometry (Schoof, 2010).

Observations near Swiss Camp upstream of Jakobshavn Isbræ serve as independent validation for the chosen functional dependence (Zwally et al., 2002; Joughin et al., 2008a; Colgan et al., 2011). Near Swiss Camp, observed annual flow increases by $2 \%$ for an annual runoff of not more than $1 \mathrm{~m} \mathrm{yr}^{-1}$. Further down the glacier and considering other outlet glaciers in the vicinity of Jakobshavn Isbræ (Joughin et al., 2008a; Colgan et al., 2011), a different picture emerges with $10 \%$ annual velocity increase for runoff rates of about $1 \mathrm{~m} \mathrm{yr}^{-1}$. At these locations however, the velocity variations are also influenced by seasonal changes at the marine termini.

\subsection{Effect of ocean warming on ice discharge}

With the aim to parameterise ocean-induced changes in ice discharge, outlet glacier accelerations are linked to oceanic warming assuming a uniform functional dependence. This choice ignores the local and regional details of the many processes that may affect the dynamics of calving glaciers and thus the ice discharge. Their representation is limited by the large-scale character of the envisaged simulation, not resolving geometric details. We therefore assume that ocean temperature changes have a first-order control on the discharge response, being aware that the individual response depends strongly on the local fjord and glacier geometries (e.g. Moon et al., 2014). Despite this non-uniform behaviour from glacier to glacier, the pattern of recent glacier accelerations is, to a certain degree, consistent with the variability in offshore ocean temperatures around Greenland (Straneo et al., 2012; Jackson et al., 2014). The functional dependence is derived by relating velocity observations (Rignot and Kana- garatnam, 2006; Moon et al., 2012) to temperature variability diagnosed from five ocean basins in available AOGCMs for the decade 2000-2010. Observations during this decade show an average speed-up of outlet glaciers in the southeast of $34 \%$ and in the northwest of $28 \%$, while other regions show no significant trend (Moon et al., 2012). Scaling these accelerations to the entire ice sheet and weighting them with the regional discharge distribution (Rignot and Kanagaratnam, 2006) results in an average ice discharge increase of about 10 to $15 \%$. This increase shows an almost linear trend over the last decade (Rignot et al., 2011). Using the residual between observed volume changes and SMB estimates from RCMs as an indicator for ice discharge changes (Sasgen et al., 2012), the decadal discharge increase explains between 25 and $40 \%$ of the total mass loss (Shepherd et al., 2012). Considering the oceanic temperature forcing at hand together with the fast marginal adjustment properties of the ice-sheet model (Fürst et al., 2013), a linear increase in discharge is best simulated by a non-linear relation between ocean temperatures and sliding velocities. In addition, results from a generalisation of the flow-line response of individual outlet glaciers to a large-scale Greenland ice-sheet application (Nick et al., 2013; Goelzer et al., 2013) support the choice for an exponential dependence. The selected relationship is calibrated such that the ice-sheet model reproduces the relative contribution of the discharge increase to the total ice loss over the last decade in response to the considered climate models.

$A_{\mathrm{S}}^{\text {outlet }}=A_{\mathrm{S}} \cdot \alpha^{\left(\Delta T_{\text {ocean }} / 1^{\circ} \mathrm{C}\right)}$

Here, $A_{\mathrm{S}}$ is the sliding factor in Eq. (1). For the tuning goal described above, we find $\alpha=5.2$. The sensitivity of the projections to changes in parameter $\alpha$ is described in Sect. 5. The amplification of the sliding factor $A_{\mathrm{S}}^{\text {outlet }}$ applies exclusively to marine-terminated glaciers using the temperature anomaly $\Delta T_{\text {ocean }}$ in the adjacent ocean basins. In this way, we circumvent directly quantifying how efficiently offshore waters enter the fjords to facilitate melt at the glacier fronts. Consequently, the parameterisation is assumed to be valid for longterm gradual ocean warming and is not applicable for shortterm warming events. In addition, any delays in the ocean system are intrinsically neglected. The forcing is applied up to $20 \mathrm{~km}$ inland from the calving front for ice grounded below sea level to account for a far-reaching loss in backstress on a length scale appropriate to longitudinal stress coupling (Nick et al., 2012; Fürst et al., 2013).

For a set of idealised experiments prescribing a linear increase in ocean temperatures under constant atmospheric forcing, the ice-sheet model shows an increase in ice discharge (Fig. 2). For a $1{ }^{\circ} \mathrm{C}$ ocean warming over 100 years, the sliding coefficient is increased by a factor 5.2 after 100 years. Yet, ice discharge does not even double. One reason is that the resultant thinning at the marine margins limits the attainable ice export (Fürst et al., 2013). Another reason is that basal velocities do not necessarily scale linearly with 
Table 1. Sensitivity of future sea-level change to main model parameters. Values from a previous tuning are indicated together with the reference values for this study. Mean and rms values are given for the ensemble projections forced with CanESM2/RCP4.5. Positive degree day factors are given in ice equivalent (i.e.).

\begin{tabular}{|c|c|c|c|c|c|c|}
\hline & & & & & 2100 & 2300 \\
\hline & $\begin{array}{r}\begin{array}{r}\text { Degree- } \\
\text { day } \\
\text { factor } \\
\text { for snow }\end{array} \\
{\left[\begin{array}{r}\text { mi.e. } \mathrm{d}^{-1} \\
\left.{ }^{\circ} \mathrm{C}^{-1}\right]\end{array}\right.}\end{array}$ & $\begin{array}{r}\begin{array}{r}\text { Degree- } \\
\text { day } \\
\text { factor } \\
\text { for ice }\end{array} \\
{\left[\begin{array}{r}\text { mi.e. } \mathrm{d}^{-1} \\
{ }^{\circ} \mathrm{C}^{-1} \text { ] }\end{array}\right.}\end{array}$ & $\begin{array}{l}\text { Enhan- } \\
\text { cement } \\
\text { factor }\end{array}$ & $\begin{array}{r}\text { Sliding } \\
\text { coef- } \\
\text { ficient } \\
{\left[10^{-10}\right]} \\
{\left[\mathrm{m}^{2} \mathrm{yr}^{-1}\right.} \\
\left.\mathrm{Pa}^{-3}\right]\end{array}$ & $\begin{array}{r}\text { Sea } \\
\text { level } \\
\text { contri- } \\
\text { bution }\end{array}$ & $\begin{array}{r}\text { Sea } \\
\text { level } \\
\text { contri- } \\
\text { bution }\end{array}$ \\
\hline Previous tuning & 0.00300 & 0.00800 & 3.50 & 1.000 & & \\
\hline Reference values & 0.00297 & 0.00791 & 3.28 & 0.83 & 9.3 & 32.7 \\
\hline parameter set 1 & 0.00303 & 0.00800 & 3.22 & 0.936 & 9.3 & 32.0 \\
\hline parameter set 2 & 0.00294 & 0.00800 & 3.28 & 0.828 & 9.0 & 30.5 \\
\hline parameter set 3 & 0.00267 & 0.00776 & 3.47 & 0.972 & 8.7 & 28.6 \\
\hline parameter set 4 & 0.00276 & 0.00749 & 3.40 & 0.936 & 8.4 & 28.2 \\
\hline parameter set 5 & 0.00285 & 0.00749 & 3.40 & 1.080 & 8.9 & 29.8 \\
\hline parameter set 6 & 0.00303 & 0.00749 & 3.28 & 1.080 & 9.0 & 30.4 \\
\hline parameter set 7 & 0.00322 & 0.00749 & 3.40 & 0.792 & 9.1 & 30.6 \\
\hline Mean & 0.00293 & 0.00770 & 3.34 & 0.932 & 9.0 & 30.1 \\
\hline rms deviation & \pm 0.00016 & \pm 0.00022 & \pm 0.08 & \pm 0.10 & \pm 0.2 & \pm 1.1 \\
\hline
\end{tabular}

changes of $A_{S}$ in a higher-order flow model. After 100 years, ocean temperatures are kept constant and ice discharge remains at an elevated level. Yet the ongoing geometric adjustment causes a general decrease of the ice discharge in this latter period.

\subsection{Glacial cycle spin-up}

In order to initialise to the present day, the model is spun up over a full glacial cycle as described in Huybrechts (2002). The ice sheet geometry evolves freely in response to past changes in regional surface temperatures, precipitation and sea level. Although the general approach is unchanged from earlier applications of this model Huybrechts (2002), the underlying reconstruction for past temperature changes is updated with recent proxy information from several ice cores (for details see Appendix A). A new compilation of accumulation observations over the Greenland ice sheet (Bales et al., 2009 ) is used as basis for scaling past precipitation changes with the mean annual temperature change (by $5 \%{ }^{\circ} \mathrm{C}^{-1}$ ). Finally, a new parameterisation to improve the retreat history from the Last Glacial Maximum is applied (Simpson et al., 2009), which is constrained by proxies for relative sea level. Switching at $3 \mathrm{kyr}$ BP from a shallow ice approximation to the higher-order formulation appeared to be sufficiently early to resolve the main effects of including horizontal stress gradients by the present day.
Using an unconstrained model evolution during the spinup phase guarantees a self-consistent model state in the present day but the geometry deviates from the observed state. Therefore, key model parameters are tuned to minimise geometric and dynamic differences after the spin-up. For a statistically sufficient and efficient coverage of the parameter space, a Latin hypercube sampling (LHS) was chosen (McKay et al., 1979), relying on 100 combinations. This sampling technique has previously been used for assessing the parameter sensitivity when spinning up ice-sheet models (Stone et al., 2010; Applegate et al., 2012; Fyke et al., 2014). We vary the positive degree-day factors for both ice $\left(\mathrm{DDF}_{\text {ice }}\right)$ and snow $\left(\mathrm{DDF}_{\text {snow }}\right)$ together with an enhancement factor $(m)$ to the rate factor and the sliding coefficient $\left(A_{\mathrm{S}}\right)$. These four parameters control both the SMB and the dynamic state of the modelled ice sheet. Parameters are selected in ranges of $75-125 \%$ for the degree-day factors, $36-450 \%$ for the enhancement factor $m$ and 50-200\% for $A_{\mathrm{S}}$ with respect to a previous calibration. Parameter ranges were estimated from the respective sensitivity of the model, known from previous tuning. For the parameter tuning, a shallow ice-approximation variant of the model was used during the entire spin-up.

Eight criteria were chosen to quantify differences between the modelled ice sheet and the observed present-day state. The minimisation reduces the mismatch of the following quantities: total ice volume; ice-covered area; ice area above $3000 \mathrm{~m}$ and below $1500 \mathrm{~m}$ surface elevation; southwest posi- 

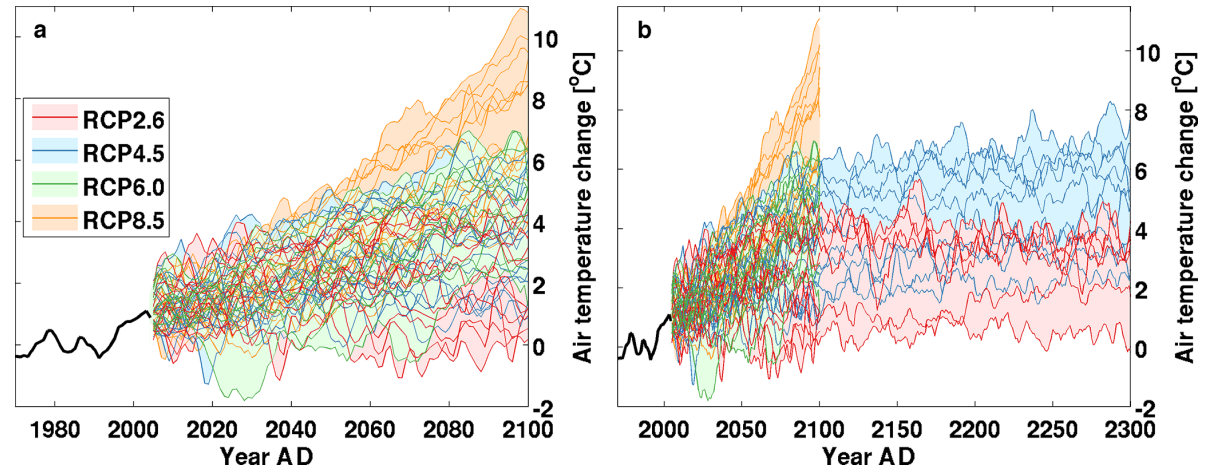

Figure 3. Mean annual surface air temperature anomaly over the present ice sheet extent with respect to the reference period 1960-1990. For illustration, the monthly temperature forcing is smoothed with a 5-year running mean. Panels cover different time periods up to 2100 (a) and 2300 (b). Thin lines represent individual projections and the lighter background shading covers the area between the minimum and maximum realisation for each RCP except when they overlap with other scenarios. Prior to the year 2005, the temperature forcing comes from the ECMWF ERA-40 and ERA-Interim meteorological reanalyses (black line).

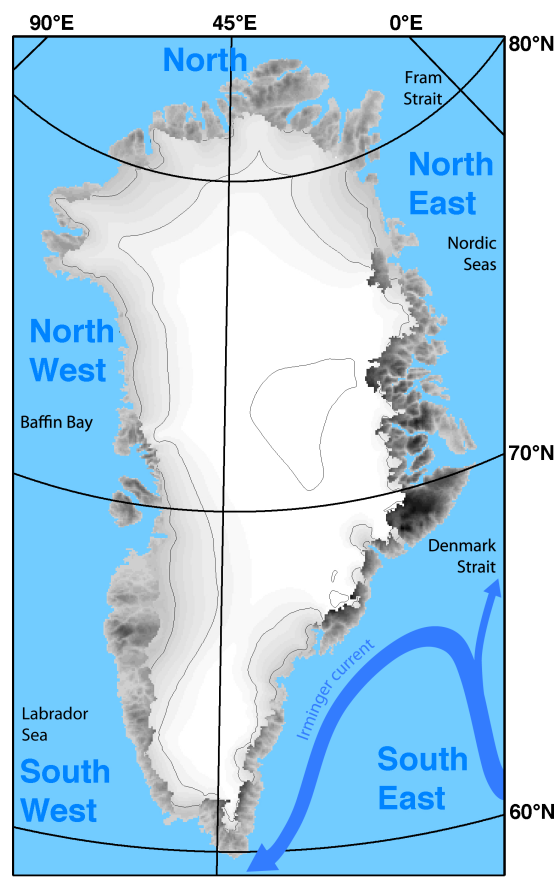

Figure 4. Observed ice sheet geometry. Surface elevation for ice sheet and bed topography are given in different grey shading. Over the ice sheet, contour lines for surface elevation are indicated with $1000 \mathrm{~m}$ spacing. The five ocean basins are labelled (bold, dark blue). They are separated by the three shown latitudes and Greenland. Oceanographic names are given in black and the Irminger Current is delineated.

tion of the land-terminated ice margin; global ice thickness and surface elevation. Instead of exclusively focussing on geometric tuning diagnostics, as in Stone et al. (2010), a final criterion evaluates the dynamic state of the ice sheet. Ice discharge in the decades prior to 1990 is assumed to have compensated for $\sim 60 \%$ of the average accumulation (Et- tema et al., 2009). This additional criterion considerably reduces the parameter space. One best-fit, reference parameter set and seven additional combinations were selected on the basis of a qualitative assessment of respectively all or individual criteria (Table 1). Very similar positive degree-day factors were found as compared to a previous tuning while parameters controlling the ice flow magnitude are slightly reduced. This reduction is necessary because of higher velocities in the ablation zone when using the parameterisation for runoff-induced speed-up.

\section{Climatic forcing}

\subsection{Reference period}

For the period 1958 to 2005 , the SMB model is forced with monthly temperature anomalies and annual precipitation ratios from a combination of ECMWF ERA-meteorological reanalysis and ECMWF operational analysis data as described in Hanna et al. (2011). Anomalies and ratios are calculated with respect to the period 1960-1990. This assumes that the ice sheet was in quasi-equilibrium with the prevailing climate of that time, as in previous studies (e.g. Hanna et al., 2005). The reference precipitation is from Bales et al. (2009). In the same way, the oceanic temperature anomalies are calculated from the atmosphere and ocean general circulation models (AOGCMs). Discontinuities in these anomalies, when switching the forcing in 1958 and 2005, are comparable to the internal climate variability of individual AOGCMs.

\subsection{Future scenarios}

For future ice-sheet simulations, climate projection data from 10 AOGCMs were selected from the WCRP's CMIP5 multimodel data set prepared for the IPCC AR5 (Taylor et al., 2012). The selection of climate models was based on the sce- 

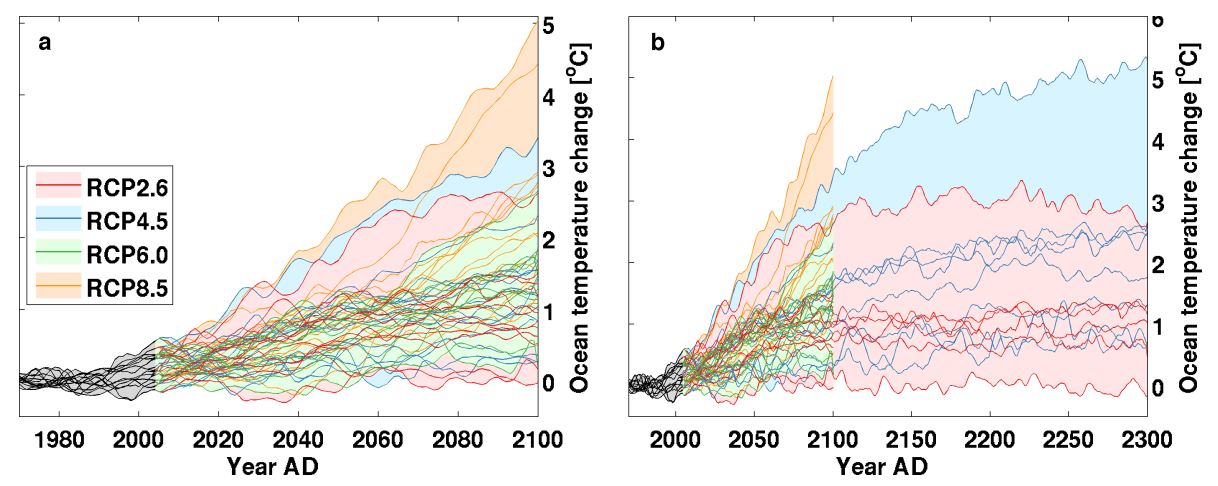

Figure 5. Mean annual ocean temperature anomaly around Greenland with respect to the reference period 1960-1990. Panels cover different time periods up to 2100 (a) and 2300 (b). Thin lines represent individual projections and the lighter background shading covers the area between the minimum and maximum realisation for each RCP except when they overlap with other scenarios. Temperature anomalies are averaged over the five ocean basins. Prior to 2005, ocean forcing is taken from each individual climate model (grey shading and black lines).

nario coverage, the covered projection period and whether surface air temperatures, averaged for 1960-1990, generally agreed with the ECMWF product. Outliers in terms of average warming by 2100 and 2300 were identified from the AOGCM ensemble and hence rejected. (Table B1 gives a complete overview of the considered AOGCMs). For these projections, the AOGCMs were forced with four CMIP5 RCP scenarios (Moss et al., 2010). The same anomaly approach as for the reference period is used to avoid any potential bias associated with the mean states. Monthly surface air temperature anomalies, annual precipitation ratios and annual ocean temperature anomalies are therefore considered with respect to the same 1960-1990 reference period.

\subsubsection{Atmospheric forcing}

Monthly surface air temperature anomalies and annual precipitation ratios are derived for each individual AOGCM over the ice-sheet model domain. These future atmospheric anomalies drive the SMB model starting from the year 2005 . In most cases, the data cover the period up to 2100 or 2300 . Missing data in the last year of two AOGCMs were filled by repeating the previous year.

The annual air temperature anomaly averaged over the present ice-sheet extent (Fig. 3) is instructive as a general trend but conceals the 2-D pattern of the warming (not shown). In general, the spatial pattern of the temperature forcing shows an expressed north-south gradient of up to $10^{\circ} \mathrm{C}$ by 2100 , with stronger warming in the north. This latitudinal gradient depends on the climate sensitivity and the polar amplification of each AOGCM. For a given latitude, the difference in warming between the east and west of the ice sheet depends strongly on the individual AOGCM. The patterns of future precipitation changes are also AOGCM dependent and cannot be generalised. Yet the average precipitation increases and scales with the scenario intensity. By 2100, the ensemble averages per RCP show 13, 19, 23 and
$37 \%$ additional precipitation for RCP2.6, RCP4.5, RCP6.0 and RCP8.5, respectively. For RCP2.6 and RCP4.5, these values increase to respectively 19 and $31 \%$ by 2300 .

\subsubsection{Ocean forcing}

Oceanic forcing is decomposed into time series for five different oceanic basins. Their delineation is based on the circulation pattern of Atlantic Water (AW) around Greenland (Straneo et al., 2012, and references therein) (cf. Fig. 4). The North Atlantic Current brings warm and saline water from the Atlantic Ocean and splits into the Irminger Current and the Norwegian Atlantic Current. The latter enters the Nordic seas where sinking occurs but AW partly submerges under fresh polar waters and continues northwards to Fram Strait. There, one portion enters the Arctic Ocean ultimately reaching the north Greenland continental shelf break (northern region). The other portion turns back at Fram Strait along the eastern flank of Greenland at intermediate depth (northeastern region). South of Denmark Strait, it joins warmer AW provided by the Irminger Current and continues southwards along the shelf break (southeastern region). At the southern tip of Greenland, it feeds into the Labrador Sea where further sinking occurs (southwestern region). A fraction of these waters remain at intermediate depth flowing northward and potentially overcome the sill into Baffin Bay (northwestern region). Warm AW with subtropical origin is therefore found at intermediate depth all around Greenland. For our projections, ocean temperature changes in these basins are related to ice discharge changes at the marine-terminating margin of the Greenland ice sheet. 

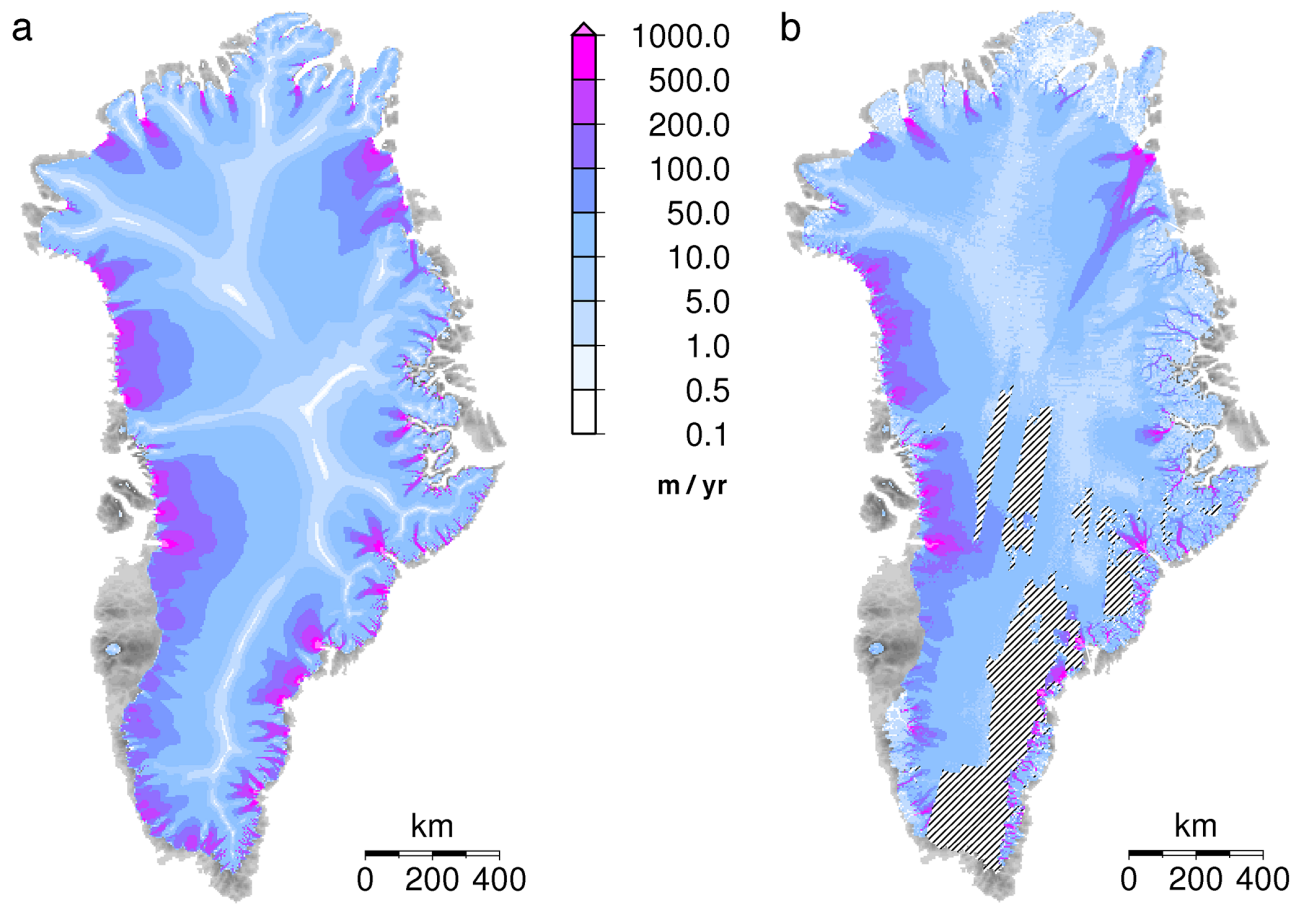

Figure 6. Comparison of present-day modelled (a) and observed (b) surface velocities. Observations are averaged over the years 2000 and 2005-2008 (Joughin et al., 2010).

Ocean circulation in the deeper ocean around Greenland, off the continental shelf, is resolved in most AOGCMs. Ocean basins are latitudinally delineated by the 60, 70, $80^{\circ} \mathrm{N}$ parallels and the North Pole at $90^{\circ} \mathrm{N}$, and confined by the Greenland coastline (Fig. 4). In each individual basin, AOGCM grid box centres that lie within a $300 \mathrm{~km}$ radius from the Greenland coastline are considered. This belt covers the continental shelf and a part of the deep ocean beyond the shelf break. The resulting basin temperature anomalies are not very sensitive to a radius increase to $500 \mathrm{~km}$. In the vertical, temperatures are averaged over a depth of 200 to $600 \mathrm{~m}$. The upper limit is inspired by the average freshwater layer thickness in Greenlandic fjords (Straneo et al., 2010, 2011, 2012) together with intermediate depth locations of offshore AW (Holland et al., 2008). The latter argument combined with the fact that Greenlandic fjords have typical sill depths of several hundred metres gives rise to the lower bound. Averaging area and depth of all AOGCM grid points in each basin provides five temperature time series for each AOGCM and each RCP.

Ocean temperature anomalies for each basin are considered with respect to the 1960-1990 average (Fig. 5). For each basin, the annual temperature anomaly records are filtered with a 5-year moving average. This is necessary to prevent high-frequency oscillations when forcing the ice-dynamic model. Though there is a tendency for stronger warming in the northern ocean basins in many of the AOGCMs, differ- ences in trends within the five basins are highly dependent on the individual climate model.

\section{Ice sheet evolution in the recent past}

After the glacial-cycle spin-up, the present-day ice-sheet geometry is in a self-consistent state concerning ice geometry, dynamics, temperature and SMB. The geometry and temperature naturally carry the long-term memory of the icesheet evolution. The main shortcoming from such a spinup is that for the present day the modelled geometry does not exactly match observations. Like in other studies with a similar spin-up technique, ice thicknesses near the margin tend to be overestimated and therefore the ice extent is somewhat larger (e.g. Huybrechts, 2002; Robinson et al., 2011; Greve et al., 2011; Graversen et al., 2011). Though the geometric mismatch biases the SMB near the margin, the icesheet-wide SMB compares well with other approaches (see below). Thicker margins also affect the modelled ice flow as margin surface slopes are somewhat reduced. A flatter ice surface leads to an underestimation of margin velocity magnitudes (Fig. 6). A side-by-side comparison shows that the locations and the magnitudes of channelised ice flow towards the marine margin are well reproduced on the $5 \mathrm{~km}$ grid. In this spin-up technique, regions of fast flow naturally arise from the interplay among deformation, sliding and thermodynamics. 
Table 2. Ice discharge prior to 2000 as inferred by Rignot and Kanagaratnam (2006) and as simulated with the ice sheet model using two resolutions. Observationally inferred values are representative of 1996 (or 2000) while simulated values are averaged over the period 1960-1990. These values therefore represent ice discharge prior to any major acceleration in the outlet glaciers. All values are given in $\mathrm{km}^{3} \mathrm{yr}^{-1}$ (bold font indicates regional values).

\begin{tabular}{lrrr}
\hline & Observations & $20 \mathrm{~km}$ model & $5 \mathrm{~km}$ model \\
\hline North & $\mathbf{5 0 . 0}$ & $\mathbf{7 6 . 7}$ & $\mathbf{7 6 . 4}$ \\
Humboldt & 3.7 & 14.2 & 6.1 \\
Petermann & 11.8 & 5.1 & 12.2 \\
Storstrømmen & 0.1 & 5.0 & 0.8 \\
Nioghalvfjerdsbræ and & & & \\
Zachariae Isbræ & 23.4 & 28.0 & 20.2 \\
\hline West & $\mathbf{1 6 5 . 8}$ & $\mathbf{1 3 2 . 9}$ & $\mathbf{1 2 9 . 0}$ \\
Jakobshavn & 23.6 & 15.8 & 21.9 \\
Rink Glacier & 11.8 & 2.2 & 4.1 \\
\hline East & $\mathbf{1 4 1 . 0}$ & $\mathbf{1 4 1 . 1}$ & $\mathbf{1 6 5 . 9}$ \\
Helheim & 26.3 & 9.9 & 26.2 \\
Kangerlussuaq & 27.8 & 16.9 & 22.0 \\
\hline Total & $\mathbf{3 5 6 . 8}$ & $\mathbf{3 5 0 . 7}$ & $\mathbf{3 7 1 . 3}$ \\
\hline
\end{tabular}

More meaningful than matching velocities at the margin is that the model is capable of reproducing ice discharge rates and their regional distribution around Greenland (Table 2). The simulated present-day state shows a total ice discharge that slightly exceeds otherwise inferred values (Rignot and Kanagaratnam, 2006). The $5 \%$ overestimation mostly arises from simulated ice-ocean contact in regions where no icesheet cover is observed, i.e. in the north and the east. A $20 \mathrm{~km}$ model spin-up is only capable of reproducing the large-scale regional distribution and the total ice discharge. Compared to this coarser model version, ice flow towards the margin is more channelised for the presented $5 \mathrm{~km}$ grid and the agreement between modelled and inferred discharge improves, on a regional level and down to the level of major outlet glaciers. The match on a drainage basin level arises naturally without specific model tuning. In this regard, the glacial-cycle spinup method is preferable to another initialisation technique that aims at inverting for observed ice velocities using the observed geometry (Gillet-Chaulet et al., 2012). Though it reproduces observed velocities, this latter initialisation technique is confronted with a strong initial model drift. Such a drift can be reduced by improving the inversion approach (e.g. Perego et al., 2014). We believe that the free-geometry spin-up, using a model with increased dynamic complexity on high resolution, provides a useful initial state for projecting the future dynamic response of the Greenland ice sheet on centennial timescales.

Averaged over the 1960-1990 period, the positivedegree-day runoff/retention approach gives a total SMB of $373 \mathrm{Gt} \mathrm{yr}^{-1}$, when forced with ECMWF ERA-reanalyses data. Other physically based models show a spread between
Table 3. Recent SMB changes in six main drainage basins. Values for four SMB model estimates are averaged from Vernon et al. (2013). The GRACE observational mass change record is corrected for ice discharge D based on Fig. 2 in Sasgen et al. (2012). SMB

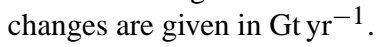

\begin{tabular}{lrrr}
\hline Drainage basin & $\begin{array}{r}\text { SMB models } \\
\text { mean } \pm \text { rms } \\
(1996-2008)\end{array}$ & $\begin{array}{r}\text { GRACE + D } \\
\text { SMB component } \\
(2002-2010)\end{array}$ & Ice sheet model \\
\hline A & $-19 \pm 6.9$ & -17 & -14 \\
B & $-15 \pm 6.8$ & -15 & -12 \\
C & $-4 \pm 5.4$ & -16 & -35 \\
D + E & $-33 \pm 15.2$ & -21 & -46 \\
F & $-54 \pm 19.4$ & -30 & -56 \\
G & $-40 \pm 7.0$ & -46 & -29 \\
\hline
\end{tabular}

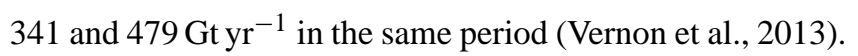
Somewhat at the lower end, the difference in our model might arise from the underlying reference precipitation map (Bales et al., 2009; Hanna et al., 2011). Moreover, recent changes in the total SMB agree fairly well between inferred values and the used positive-degree-day approach (Table 3). SMB changes estimated from observations and given by various other model approaches (Sasgen et al., 2012; Vernon et al., 2013) can be compared on the basis of six main drainage basins (Hardy et al., 2000). On this drainage basin level, differences among various methods become more expressed. For one drainage basin (in southeast Greenland; $\mathrm{C}$ in Table 3), discharge-corrected observations from GRACE cannot be reconciled with any model estimate. This indicates some large remaining uncertainties in both modelled SMB changes and otherwise inferred estimates. However, in most cases our SMB model reproduces the trends of other models within stated uncertainty bounds.

When forced with ECMWF atmospheric reanalysis data and using ocean temperatures from one climate model with expressed warming over that period (i.e. HadGEM2ES in Table B1), the simulated ice sheet loses mass at a rate of $0.62 \mathrm{~mm} \mathrm{yr}^{-1}$ for the period 2005-2010. This is in good agreement with the inferred average trend of $0.7 \pm$ $0.1 \mathrm{~mm} \mathrm{yr}^{-1}$ (Shepherd et al., 2012). For this same forcing scenario, the model simulates $\sim 41 \%$ (or $0.25 \mathrm{~mm} \mathrm{yr}^{-1}$ ) of the mass loss as arising from increased discharge. For the full ensemble of climate models, the average mass loss rate for the period 2005-2010 is lower at $0.32 \mathrm{~mm} \mathrm{yr}^{-1}$. This reflects that AOGCMs are not expected to correctly reproduce the real trend over such a short time period. The climate system shows an inherent variability which is also seen in climate models. Yet the timing of this variability is not expected to match. Therefore climate models have difficulties to reproduce short-term trends. For the ensemble member with the highest initial oceanic and atmospheric warming, the sealevel contribution reaches a maximum rate of $0.71 \mathrm{~mm} \mathrm{yr}^{-1}$ for the period 2005-2010. This might suggest that the Greenland ice sheet is for now responding to the upper end of tem- 
Table 4. Ice-sheet-wide mean atmospheric warming, basin-mean oceanic warming, and ensemble-average contribution of the Greenland ice sheet to global sea-level change by 2100 and 2300. Sea-level changes are calculated with respect to the year 2000. Ensemble averages for each scenario use equal weights for individual AOGCMs. The root mean square deviation from the mean ensemble realisation is added to estimate the variability.

\begin{tabular}{lrrr|rrr}
\hline & \multicolumn{3}{c|}{2100} & & 3 & 2300 \\
\hline $\begin{array}{l}\text { Climate } \\
\text { scenario }\end{array}$ & $\begin{array}{r}\text { Atmospheric } \\
\text { warming } \\
\left({ }^{\circ} \mathrm{C}\right)\end{array}$ & $\begin{array}{r}\text { Oceanic } \\
\text { warming } \\
\left({ }^{\circ} \mathrm{C}\right)\end{array}$ & $\begin{array}{r}\text { Sea-level } \\
\text { contribution } \\
(\mathrm{cm} \text { s.l.e. })\end{array}$ & $\begin{array}{r}\text { Atmospheric } \\
\text { warming } \\
\left({ }^{\circ} \mathrm{C}\right)\end{array}$ & $\begin{array}{r}\text { Oceanic } \\
\text { warming } \\
\left({ }^{\circ} \mathrm{C}\right)\end{array}$ & $\begin{array}{r}\text { Sea-level } \\
\text { contribution } \\
(\mathrm{cm} \text { s.l.e. })\end{array}$ \\
\hline RCP2.6 & $2.10 \pm 1.53$ & $1.12 \pm 0.57$ & $4.23 \pm 1.80$ & $2.59 \pm 1.62$ & $1.32 \pm 0.73$ & $8.82 \pm 4.48$ \\
RCP4.5 & $3.56 \pm 1.86$ & $1.62 \pm 0.67$ & $5.50 \pm 1.86$ & $5.27 \pm 1.62$ & $2.77 \pm 1.18$ & $20.11 \pm 8.03$ \\
RCP6.0 & $4.00 \pm 1.59$ & $1.43 \pm 0.22$ & $5.40 \pm 1.49$ & - & - & - \\
RCP8.5 & $7.15 \pm 1.98$ & $2.68 \pm 0.94$ & $10.15 \pm 3.24$ & - & - & - \\
\hline
\end{tabular}

perature changes provided by the CMIP5 climate model ensemble.

Over all climate models and scenarios, this approach gives an average increase in ice discharge of about $0.14 \mathrm{~mm} \mathrm{yr}^{-1}$ with a maximum of $0.23 \mathrm{~mm} \mathrm{yr}^{-1}$ for the period 2005 to 2010 with respect to the average value in the 1990s. The average increase in discharge caused by the climate model ensemble produces the inferred $\sim 40 \%$ share of the total mass loss. However, the mean is at the lower end of observations during this period and results from a weak oceanic warming around Greenland over the last decade in the used climate models (Fig. 5).

\section{Future projections}

Figure 7 and Table 4 summarise the volume projections of the Greenland ice sheet for all models and all scenarios under investigation. A breakdown by individual climate models is presented in Appendix B. By 2100, the full model and scenario range of Greenland sea-level contributions is between 1.4 and $16.6 \mathrm{~cm}$ (Fig. 7 and Table B1). This range is slightly higher than the $1-12 \mathrm{~cm}$ found for the IPCC AR4 (Meehl et al., 2007), which included the additional uncertainty arising from the SMB model. The higher maximum in sea-level projections is somewhat unexpected because the RCP scenarios have a reduced upper bound for radiative forcing by 2100 , when compared to the previously used scenarios. Yet the larger range is attributed to directly accounting for future changes in ice discharge. In terms of the SMB contribution to future ice loss, the IPCC AR5 (Church et al., 2013) gives a range of $1-11 \mathrm{~cm}$, confirming the results of the previous AR4. Yet the AR5 is the first to attempt to quantify the contribution from future changes in ice discharge. It states an additional contribution from dynamic changes of $1-9 \mathrm{~cm}$ for all RCP scenarios. The new AR5 is however not able to quantify the importance of the interaction between ice dynamics and surface mass balance, as it suffers from the fact that the considered studies are not directly comparable either in terms of forcing or setup.
Until 2050, there is hardly any difference in the mean sealevel contribution among the four scenarios. This is in agreement with similar behaviour for the underlying atmospheric and oceanic forcings (Sect. 3.2.1). The ensemble spread in sea-level evolution for each scenario arises from the different climate trajectories followed by the individual AOGCMs. This spread is largely overlapping during the first century for three scenarios. The exception is RCP8.5, a high-impact scenario assuming a high-emission, fossil-fuel-orientated world. This scenario causes a mean centennial sea-level contribution of $10.2 \mathrm{~cm}$, which is about twice as large as for other RCPs. The reason is an average warming of $\sim 7^{\circ} \mathrm{C}$ over Greenland that is also more than twice as high as for other RCPs. In addition, RCP8.5 is the only scenario for which mass loss rates significantly increase throughout the next century.

As AOGCM input was not available for RCP6.0 beyond 2100 and as the divergent temperature response of the few AOGCMs under RCP8.5 is not considered compatible with our ensemble approach, projections were continued until 2300 only for the two lowest emission scenarios. Both assume a stringent climate policy with a focus either on terrestrial carbon for mitigation (RCP4.5) or on negative emissions (RCP2.6). Both scenarios aim for a climate stabilisation but only RCP2.6 has a peak greenhouse gas concentration before 2100 and declines afterwards (Moss et al., 2010). For both scenarios, the Greenland contribution to global sea-level rise increases continuously, but for RCP2.6 the rate of increase gradually levels off. In this case, the SMB remains positive in the last decade of the projection. Therefore, it appears that a new ice-sheet equilibrium with limited ice loss $(<20 \mathrm{~cm}$ of sea-level rise) is attainable. For RCP4.5, the rate of mass loss is almost constant over 300 years with a total volume loss equivalent to $20.1 \mathrm{~cm}$ sea-level increase. Average SMB values during the last decade are negative for most ensemble members. A typical thinning pattern for RCP4.5 shows extensive marginal thinning and inland retreat of calving fronts after 300 years (Fig. 8). Mass loss near the margin is partially balanced by increased snow accumulation and thickening in the interior. 

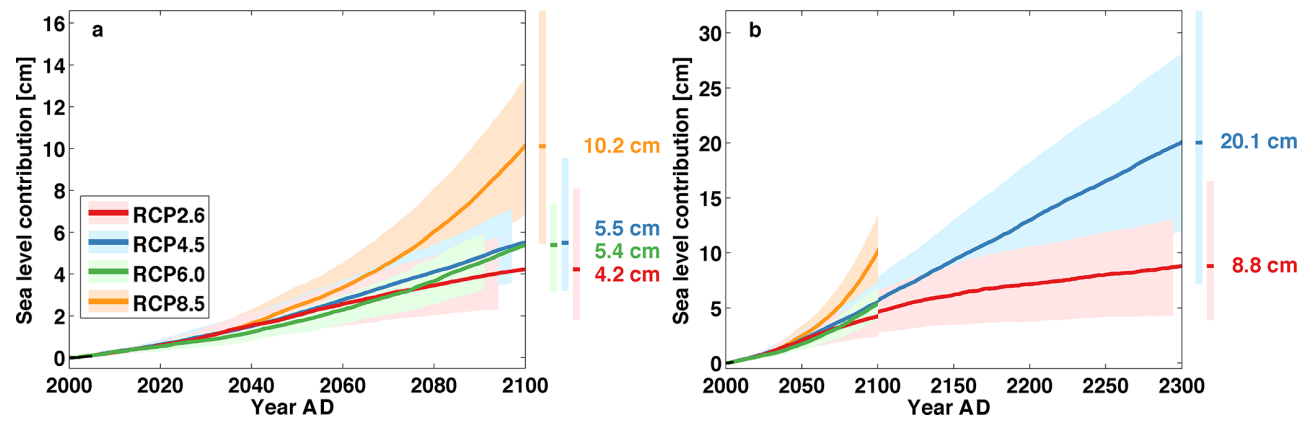

Figure 7. Greenland ice sheet contribution to future global sea-level change. Given are ensemble averages for each scenario during the 21 st century (a) and the next 3 centuries (b). The modelled rate of mass loss during the observational period (2000-2010) is on average $0.32 \mathrm{~mm} \mathrm{yr}^{-1}$. Colours indicate the respective RCP scenario and the lighter background colour represents 1 standard deviation from each mean trajectory. Vertical bars indicate the spread of sea-level contributions arising from individual AOGCMs at the end of each scenario. The jump across the year 2100 in the right panel arises from the use of a different number of climate models in simulations out to 2100 vs. out to 2300 .

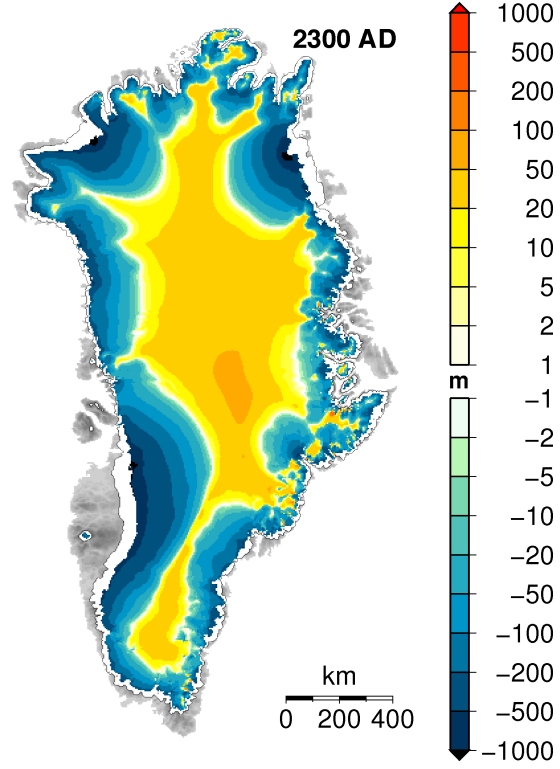

Figure 8. Total ice thickness change by 2300. The initial ice extent is indicated with a black contour line while thickness changes are exclusively shown within the ice extent at the end of the experiment. This particular result for RCP4.5 was obtained with CanESM2, which shows most expressed warming over Greenland for all climate models in the ensemble (Table B1). The thinning patterns for other ensemble members are qualitatively similar.

In all climate scenarios, oceanic warming causes additional mass loss from the ice sheet by 2100 (upper dark blue columns in Fig. 9). This comprises both the directly induced changes in ice discharge and their effect on the SMB via icesheet thinning. For individual AOGCM projections, the inclusion of oceanic forcing can explain more than $50 \%$ of the total contribution to sea-level rise by a given time period with an average increase of the total mass loss by $\sim 40 \%$. In absolute terms, the ocean-induced contribution to sea-level change ranges from 1.8 to $2.6 \mathrm{~cm}$ (scenario averages) and 1.1 to 3.2 (full spread) after 1 century, and from 3.8 to $5.4 \mathrm{~cm}$ after 3 centuries (full spread is 2.3 to $7.4 \mathrm{~cm}$ ). The oceanic influence on the total ice loss becomes relatively less important for more intense atmospheric warming; while it explains about half of the mass loss for RCP2.6, it only explains $27 \%$ of the mass loss for RCP8.5. This indicates that decreasing SMB and increasing discharge are mutually competitive processes for ice removal at the marine margin. In addition, ice further upstream is efficiently removed by ablation before it actually reaches the marine margin for calving. The oceanic forcing typically induces a diffusive thinning wave at the marine margin which is gradually transmitted inland (Fig. 10a). In areas with a marine margin, this additional thinning wave explains a large share of the total thinning (Figs. 8 and 10a).

In Fig. 9, we also attribute simulated mass changes to either changes in ice discharge, arising from oceanic forcing and inland ice dynamics, or from changes of the mass balance at the ice sheet surface or base (although in all cases, basal melting contributes less than $3 \%$ of the total land ice loss). While increased discharge explains about $40 \%$ of the average mass loss between 2000 and 2010 (light blue columns), its relative contribution generally decreases afterwards and changes in SMB become the dominant factor in mass loss. This is because total ice export across calving fronts eventually falls below year 2000 levels, despite warmer ocean temperatures. Limitations on the ice discharge increase are a direct result of gradual thinning at the marine margins with a fast adjustment of the ice inflow from upstream (Fürst et al., 2013) but are also a consequence of a retreat of the ice-sheet margin back on land. For the CanESM2 model under RCP4.5, the ice sheet loses more than half of its contact area with the ocean by 2300 (Fig. 8). In general, ice discharge increase is more relevant for the total mass loss in emission scenarios with higher mitigation efforts (RCP2.6, $\mathrm{RCP} 4.5)$. The reason is that an ice discharge increase causes 

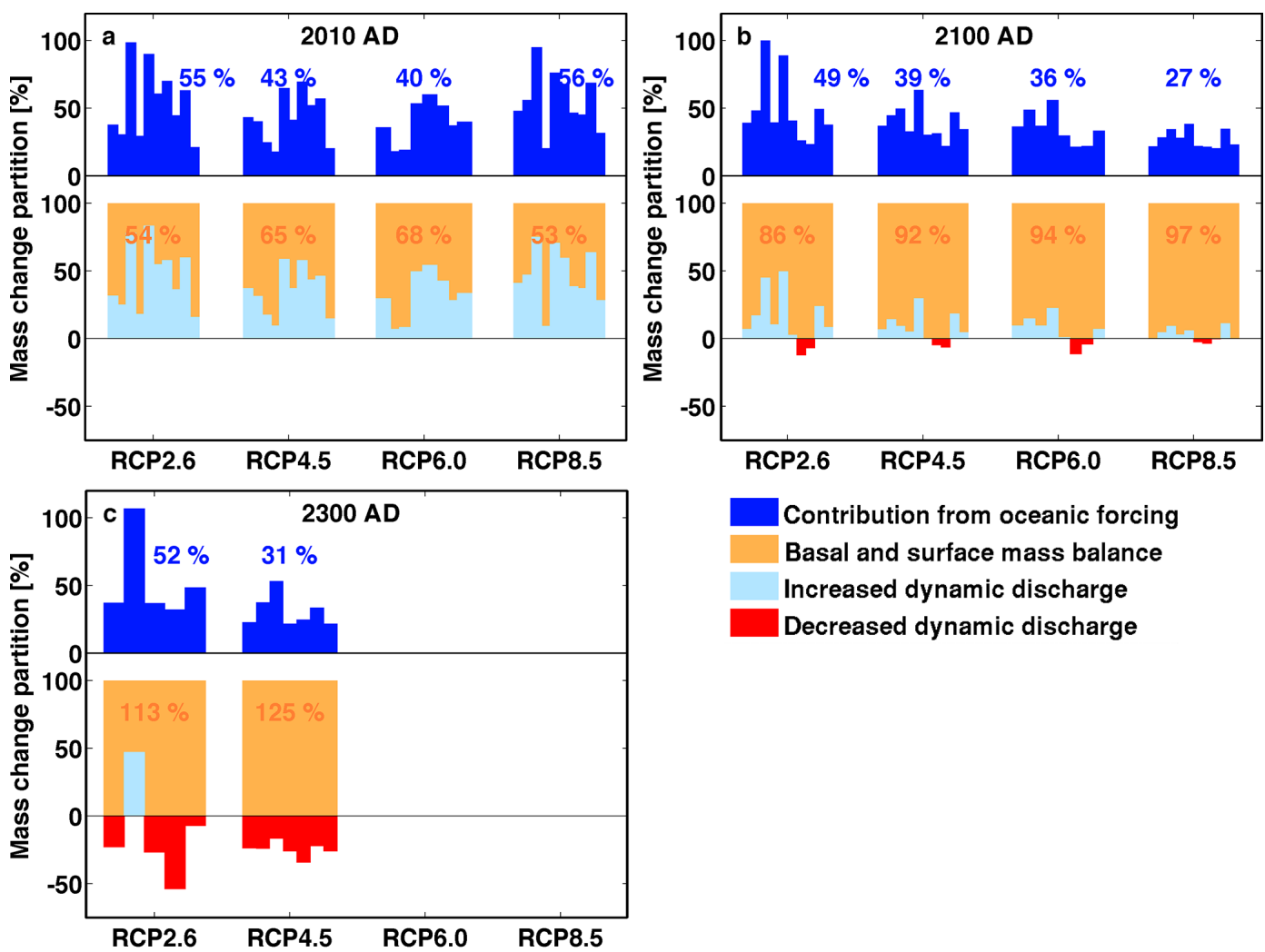

Figure 9. Partitioning of mass changes by 2010 (a), 2100 (b) and 2300 (c). Values are given relative to the total ice loss of the individual AOGCM projection and grouped by climate scenario. Each vertical column represents one AOGCM projection. The dark blue columns denote the contribution to the total mass change arising from oceanic forcing, diagnosed from a control run with SMB forcing only. The diagnostics comprise the directly induced ice discharge changes as well as the indirect feedback with the SMB via the ice geometry. The mass change of the projections is subsequently partitioned into contributions from changes in both basal melt and SMB (orange columns) or in ice discharge (light blue and red columns). The presented partitioning of the mass change is cumulative. Changes with respect to the average 1990-2000 values of all contributors in the mass budget are integrated over time. The scenario averages are then given in per cent. At a certain point in the future, ice discharge falls below present-day values and therefore becomes a source term in the mass partitioning. Consequently, the cumulative sea-level contribution from ice discharge changes can become negative (red).

dynamic thinning further upstream, draws down the ice surface to lower and warmer elevation, and thereby intensifies surface melting. Surface melting in turn competes with the discharge increase by removing ice before it reaches the marine margin. Margin thinning and retreat limit the ice discharge and increase the relative importance of surface melting in the future volume evolution. The total 2100 ice loss, from SMB changes only, increases by more than $70 \%$ when including ice-ocean interaction. This share is about $42 \%$ of the combined total ice loss in 2100 (Fig. 9b), but only $10 \%$ of it is directly caused by ice discharge increase at the marine margin. By 2300, the cumulative effect from ice discharge changes becomes even negative as ice discharge rates have, on average, fallen below the pre-2000 level.

Detailed flow-line projections of the ice discharge evolution of four major outlet glaciers on Greenland show a general increase by 2100 and 2200 (Nick et al., 2013). Such a widespread increase of ice discharge is not confirmed by our projections. The glaciers in the Nick et al. (2013) study are however driven with only one specific climate model and only represent the response of four individual, well-studied outlet glaciers. In our large-scale model approach, ice discharge of main outlet glaciers can also show a significant increase while the ice-sheet-wide discharge increase is more moderate. This is because many of the smaller glaciers become land-based. Therefore, scaling up the discharge response of only those glaciers with the most prolific ice export is not necessarily representative of the future ice-dynamic evolution of an entire ice sheet. A generalisation of the discharge evolution of the four outlet glaciers modelled in Nick et al. (2013) to the entire ice sheet is in line with our finding that the relative importance of ice discharge changes to the future ice loss is self-limited by thinning and retreat of ice in contact with the ocean (Goelzer et al., 2013). Though not linking ice discharge changes directly to climatic variables, other projections of the Greenland ice sheet under future warming also found evidence for this self-limiting effect (Gillet-Chaulet et al., 2012; Lipscomb et al., 2013). 

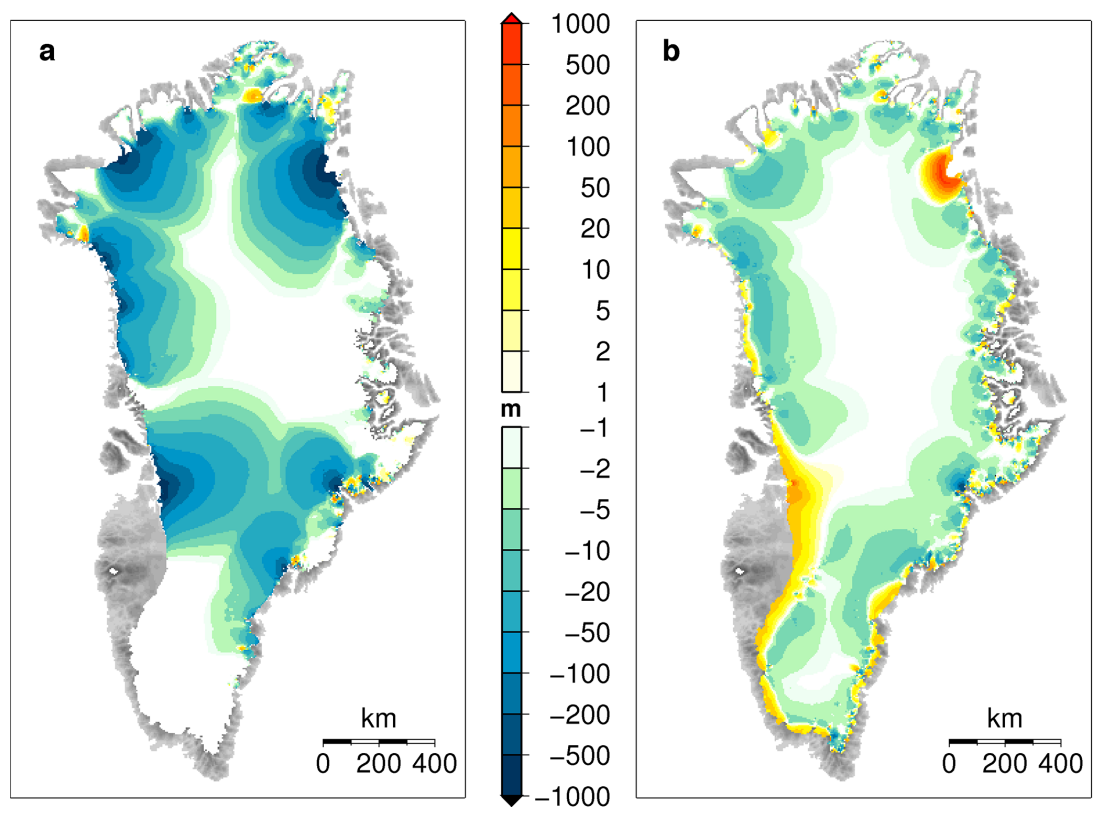

Figure 10. Ice thickness changes from ocean warming-induced discharge increase (a) and runoff-induced lubrication (b). In this particular experiment, obtained with CanESM2 for RCP4.5, additional oceanic forcing accounts for $7.4 \mathrm{~cm}$ of the total sea-level contribution of $32.0 \mathrm{~cm}$. The effect of basal lubrication increases mass loss by $0.1 \mathrm{~cm}$. This small extra contribution results from a general ice displacement expressed by relative thinning of the upper ablation area and resulting thickening of the marine margin (as shown in Shannon et al., 2013).

Table 5. Sensitivity of future sea-level contribution from the Greenland ice sheet to the parameterisation of ocean warming-induced discharge increase. Values are ensemble averages with respect to the year 2000, given in $\mathrm{cm}$ s.l.e.

\begin{tabular}{|c|c|c|c|}
\hline & $\alpha=1.8$ & $\alpha=2.6$ & $\alpha=5.2$ \\
\hline $\begin{array}{l}\text { Climate } \\
\text { scenario }\end{array}$ & $\begin{array}{r}\text { sea-level } \\
\text { contribution by } \\
2100 / 2300\end{array}$ & $\begin{array}{r}\text { sea-level } \\
\text { contribution by } \\
2100 / 2300\end{array}$ & $\begin{array}{r}\text { sea-level } \\
\text { contribution by } \\
2100 / 2300\end{array}$ \\
\hline RCP2.6 & $3.18 / 6.86$ & $3.58 / 7.77$ & $4.23 / 8.82$ \\
\hline RCP4.5 & $4.36 / 17.46$ & 4.77 / 18.63 & $5.50 / 20.11$ \\
\hline RCP6.0 & $4.38 /-$ & $4.77 /-$ & $5.40 /-$ \\
\hline RCP8.5 & $8.65 /-$ & $9.29 /-$ & $10.15 /-$ \\
\hline
\end{tabular}

In all experiments, the additional effect of basal lubrication on total mass loss is very small, corresponding to an additional sea-level contribution of less than 1\% (Fig. 10b). This is in agreement with recent observational evidence (Tedstone et al., 2014) and results from a parametric approach to link runoff to basal lubrication (Shannon et al., 2013). As also shown by Shannon et al. (2013), lubricationinduced speed-up displaces inland ice mass from the interior towards the coast, but in general does not remove it. In the upper ablation area, the ice thins as it accelerates, while for melt rates exceeding $2 \mathrm{~m} \mathrm{yr}^{-1}$ near the margin, the relative speed-up decreases under warming, causing a relative thickening (Fig. 10b, also see Eq. 2 and Fig. 1). The rea- son is that when meltwater export rates exceed a threshold, a channellisation of the basal drainage system is assumed with concurrent reduction of basal lubrication. Ice flow is mainly enhanced close to the equilibrium line where runoff rates cause maximal speed-up. This may even lead to a negative feedback as the relative thickening of the ablation zone reduces runoff rates through the height-mass-balance feedback (Huybrechts et al., 2002).

For both projection periods to 2100 and 2300 , the mass loss projections do not depend much on the parameters tuned during the model spin-up (Sect. 2.4). For seven additional and acceptable parameter sets (Table 1), the future sea-level contribution lies within $4 \%$ of the reference model (i.e. \pm 2 or $\pm 12 \mathrm{~mm}$ by 2100 or 2300 , respectively). The sensitivity of the projections to the parameterisation for warming-induced discharge increase (Eq. 3) is assessed from additional results for the full ensemble obtained with $\alpha=1.8$ and 2.6. For the period 2000-2010, we find that the relative contribution from ice discharge to total mass loss is $\sim 20, \sim 27$ or $\sim 40 \%$ for $\alpha$ equal to $1.8,2.6$ or 5.2 , respectively. The effect on the projections is however somewhat reduced, as ice discharge increase is even more limited. For the sea-level projections (Table 5), variations reach $\sim 25 \%$ compared to the reference run $(\alpha=5.2)$. Relative to increasing values for $\alpha$, a saturation of the ice loss increase can be stated. The root-meansquare (rms) deviation around these ensemble values is not much affected by the choice of $\alpha$, and differences mostly fall below $10 \%$. If one excludes the value 1.8 , as the $2000-2010$ contribution from ice discharge in this case is rather low, dif- 
ferences between ensemble-mean mass loss lie within $15 \%$ of the standard results. In this case, the sensitivity to changes in $\alpha$ of the mass loss in 2300 is about $10 \%$, even lower than in 2100. For $\alpha$ values of 2.6 and 5.2, ocean forcing explains about 30 or $40 \%$ of the total mass loss in 2100 , respectively. By increasing $\alpha$ beyond 5.2, the present-day ice discharge can certainly be increased further. If the value is chosen such that the present discharge contribution stays in a realistic range, we would however not expect the projection results to qualitatively change. In summary, the projections are sensitive to the choice of $\alpha$ but the sensitivity decreases with the length of the projection period and the warming magnitude. Despite this sensitivity, the spread in future ice loss, introduced by the climate model ensemble, is several times larger (Table 4). This is in line with other studies recognising the importance of the climate trajectory as the main source for the large spread in sea-level projections of the Greenland ice sheet (e.g. Yoshimori et al., 2011; Quiquet et al., 2011; Fyke et al., 2014).

\section{Summary and conclusion}

In this study, we included additional dynamic processes in a thermomechanically coupled, three-dimensional ice flow model, with the aim of better assessing the impact of ice dynamics on the future evolution of the Greenland ice sheet. We suggested parameterisations that link ice discharge increase to ocean warming and allow for runoff-induced lubrication. To assess the likely range of the future contribution from the Greenland ice sheet to sea-level change, climate anomalies were taken from a suite of 10 atmosphere-ocean general circulation models (Table B1). They were selected from the WCRP's CMIP5 multi-model data set prepared for the IPCC AR5 (Taylor et al., 2012) and forced by four RCP climate scenarios. When considering climate forcing from ECMWF reanalysis data and ocean temperatures from an AOGCM that shows an expressed warming over the period 2005-2010, we find an ice loss rate of $0.62 \mathrm{~mm} \mathrm{yr}^{-1}$ over the same period that is explained by $\sim 40 \%$ from increased ice discharge, in agreement with the observational range. Changes in ice discharge are attributed to oceanic warming in the surrounding ocean basins. The mean ice volume loss for the CMIP5 ensemble is however biased low with $0.32 \mathrm{~mm} \mathrm{yr}^{-1}$. This bias arises from the spread in climate models that are not expected to correctly simulate the observed trend over such a short period of time. The ensemble maximum of the ice loss during this recent period is $0.71 \mathrm{~mm} \mathrm{yr}^{-1}$ and equally covers values inferred from observations. For the climate model ensemble, increased ice discharge also explains $\sim 40 \%$ of the total mass loss during the last decade.
Accounting for the four RCP scenarios, we find a Greenland ice-sheet contribution to global sea-level rise of between 1.4 and $16.6 \mathrm{~cm}$ by 2100 . For the two low-impact scenarios, ice loss attains respectively 11.1 and $32.0 \mathrm{~cm}$ by 2300 . Despite an average increase in mass loss of $\sim 40 \%$ in 2100 , when accounting for ice-ocean interaction, mass loss is predominantly caused by changes in SMB. The reason is that ice discharge is limited by margin thinning and retreat as well as by a competition with surface melting that removes ice before it reaches the calving fronts. These geometric limits on ice discharge explain that most of the mass loss by 2100 is caused by changes in SMB. Beyond 2100, modelled ice discharge rates fall below the pre-2000 level and this decrease is compensated by the dominant changes in SMB. The results therefore suggest that the largest source of uncertainty in future mass loss arises from the SMB and the underlying climate change projections, and not from ice dynamics.

Our results have implications for attempts to estimate the role of ice discharge on the future mass loss of the Greenland ice sheet. Observed rates of change over the last decade cannot simply be extrapolated over the 21 st century on account of a different balance of processes causing mass loss over time. Extrapolating recently inferred mass trends (Pfeffer et al., 2008) or even changes therein to a century timescale (Rignot et al., 2011) or linking observed Greenland sea-level trends to temperature change (Rahmstorf, 2007) implies continued glacier acceleration and a multifold increase of the ice discharge that is not found attainable in numerical ice-sheet models. Ice discharge at calving fronts is self-limited by ice dynamics, supporting the view that centennial mass changes are dominantly driven by SMB changes, and thus by changes in surface climate conditions. 
Appendix A: Climate conditions over the last glacial cycle

\section{Temperature history}

The model spin-up over several glacial cycles requires information on the past climate, which is reconstructed from ice core data. The glacial temperature forcing is obtained from synthesised isotope records representative of central Greenland conditions. For the period prior to $122.6 \mathrm{kyr} \mathrm{BP}$, the forcing reconstruction is based on a synthesised Greenland $\delta^{18} \mathrm{O}$ record derived from Antarctica Dome $\mathrm{C}$ using a bipolar seesaw model (Barker et al., 2011). Subsequently, the NGRIP $\delta^{18} \mathrm{O}$ record (Andersen et al., 2004) is used before switching to GRIP information at $103.8 \mathrm{kyr}$ BP (Dansgaard et al., 1993). For the last $4 \mathrm{kyr}$, a direct reconstruction of snow temperatures is available based on a $\delta^{15} \mathrm{~N} / \delta^{40} \mathrm{Ar}$ record from GISP2 (Kobashi et al., 2011).

The synthesised $\delta^{18} \mathrm{O}$ record from Barker et al. (2011) matches well with the GRIP record. Therefore, the fabricated isotope values are transformed into temperature changes according to one single transfer function as given by Huybrechts (2002). For the NGRIP record the same transfer function gives lower temperatures during the Last Glacial Maximum compared to the GRIP reconstruction. For the purpose of splicing NGRIP to GRIP, an overlap period for rescaling the transfer function is defined between 102.4 and $90.9 \mathrm{kyr}$ BP. Since present-day $\delta^{18} \mathrm{O}$ values match between GRIP and NGRIP, only the scaling factor is adjusted from 2.40 to $2.13 \mathrm{~mm} \mathrm{yr}^{-1}$. By replacing information from GRIP with NGRIP during the period 122.6-103.8 kyr BP, the spliced record does not contain the disturbed lower part of the GRIP ice core. The Kobashi et al. (2011) snow temperature reconstruction for the last $4 \mathrm{kyr}$ is offset by its average of $-19.6^{\circ} \mathrm{C}$ during the reference period $1960-1990$. Thereafter, the temperature reconstruction shows a mismatch of $0.4{ }^{\circ} \mathrm{C}$ with the GRIP reconstruction at $4 \mathrm{kyr}$ BP. Before splicing these two records, the Kobashi et al. (2011) temperatures are lowered over time with a linear function that removes the past mismatch but keeps the present-day values (Fig. A1). In a final step, the temperature reconstruction is linearly interpolated on time intervals of 10 years.
Assembling the forcing record in this way prolongs any records exclusively based on Greenland ice cores by several hundred millennia. In addition, the intermediate switch to the NGRIP record gives more reliable information during the late Eemian period than GRIP. This is because of known disturbances in the lower parts of the GRIP ice core prior to $105 \mathrm{kyr}$ BP. The last splice with surface snow temperature reconstructions at GISP2 seems favourable because this reconstruction method was validated against observations and model reconstructions starting in 1850 . One remarkable feature of our assembled temperature forcing record is the Little Ice Age cooling on the Greenland ice sheet (Fig. A1). This cold period 200-500 years ago influences our spin-up into the present day and causes ice-sheet growth up to the beginning of the 20th century. 


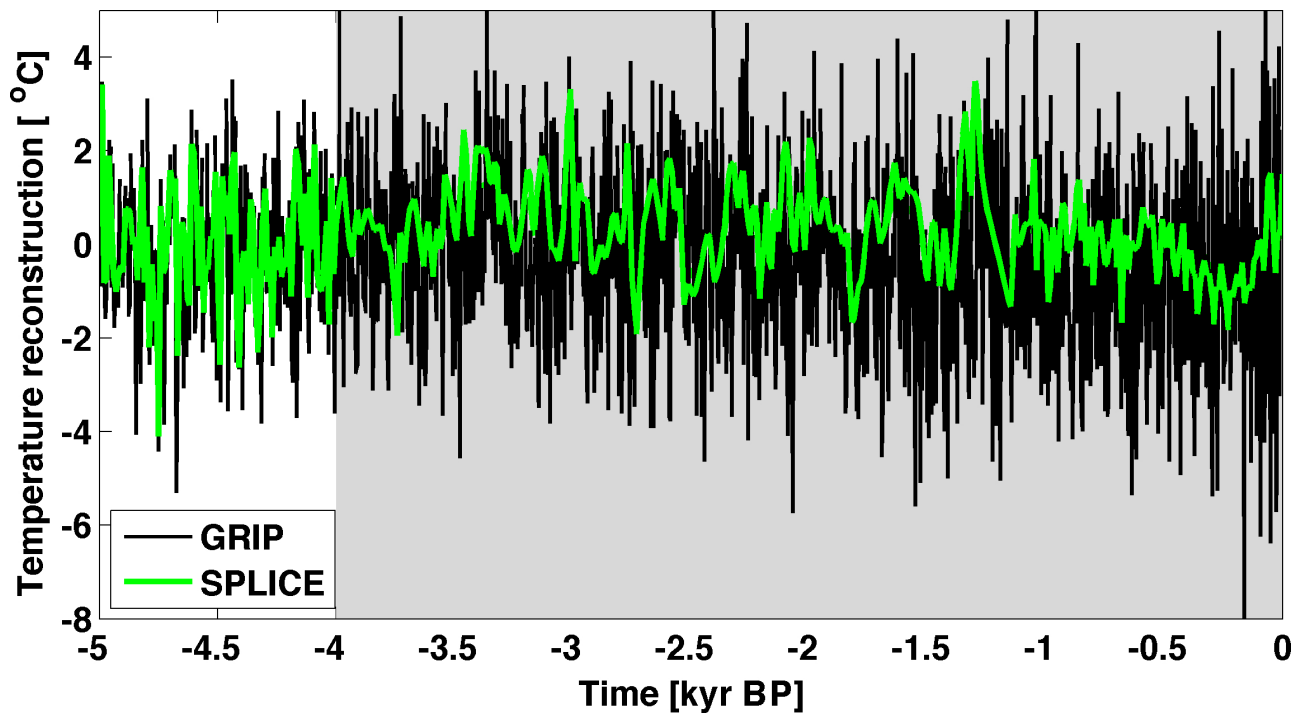

Figure A1. Assembled temperature forcing during the last $5 \mathrm{kyr}$ based on the $\delta^{18} \mathrm{O}$ GRIP ice core record and a direct temperature reconstruction. The splicing point of these two records is indicated by a change in the background shading at $4 \mathrm{kyr}$ BP. Note that the original GRIP record shows sub-decadal resolution during the Holocene period while the temperature forcing, used here, is linearly interpolated for a decadal sampling rate. 
Appendix B: Breakdown of projections by climate model

For most of the climate model ensemble members (Table B1), air temperature anomalies correlate better with the centennial contribution of the Greenland ice sheet to sealevel change than ocean temperature anomalies. Linear correlation coefficients for air temperature in general exceed 0.7 while this threshold is not surpassed for ocean temperatures except in RCP8.5. By 2300, the correlation with ocean forcing dominates for RCP2.6. The spread in centennial sea-level contributions and atmospheric warming (Fig. B1) reflects both uncertainties in the realised future scenario and differences in the respective AOGCM. Up to 2100, this spread is explained by differences in individual AOGCM projections rather than scenario differences. In particular the three lowimpact scenarios show a large overlap in AOGCM realisations. By 2300, the spread introduced by the different scenarios is largest. For the two lowest scenarios, the 2300 temperature spread remains similar to the centennial spread while deviations in sea-level contribution become more than twice as large.
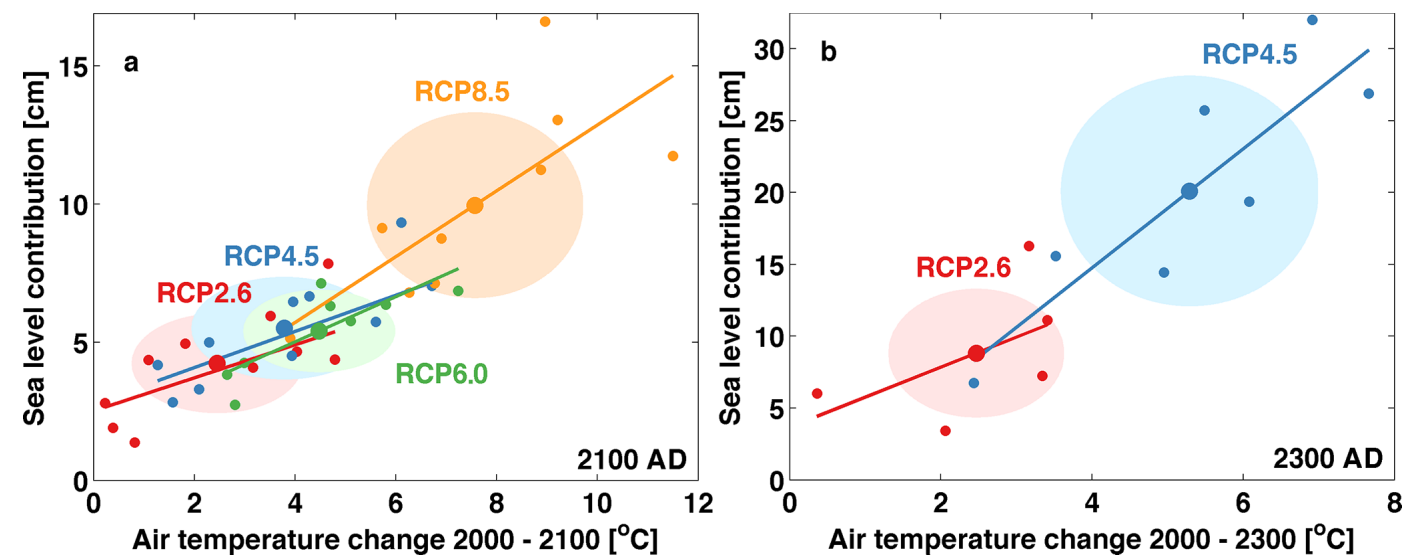

Figure B1. Greenland ice sheet contribution to global sea level change as a function of regional atmospheric warming by 2100 (a) and 2300 (b). Temperature changes are taken as differences between $10 \mathrm{yr}$ averages at either end of the projection period. Small dots represent each individual realisation with colours indicating the RCP scenario. The respectively coloured lines are a linear fit to each RCP response. Larger dots indicate the model averages for each RCP. Ellipses indicate rms deviations in both temperature change and sea-level change. 
Table B1. Atmospheric and oceanic temperature forcing as provided by the AOGCMs given together with the resulting Greenland ice sheet contribution to sea-level change by 2100 and 2300. Sea-level contribution is determined with respect to 2000. Ocean temperatures are basin averages. Also provided are model means and root mean square deviations (RMSDs) from the mean for each RCP scenario. En dashes indicate no data for the selected model and period. Ensemble averages are given in bold.

\begin{tabular}{|c|c|c|c|c|c|c|}
\hline \multirow[b]{2}{*}{$\begin{array}{l}\text { Climate } \\
\text { scenario } \\
\text { and model }\end{array}$} & \multicolumn{3}{|c|}{2100} & \multicolumn{3}{|c|}{2300} \\
\hline & $\begin{array}{r}\text { Air } \\
\text { temperature } \\
\text { change } \\
\left({ }^{\circ} \mathrm{C}\right)\end{array}$ & $\begin{array}{r}\text { Ocean } \\
\text { temperature } \\
\text { change } \\
\left({ }^{\circ} \mathrm{C}\right)\end{array}$ & $\begin{array}{r}\text { Sea } \\
\text { level } \\
\text { contribution } \\
\text { (cm s.l.e.) }\end{array}$ & $\begin{array}{r}\text { Air } \\
\text { temperature } \\
\text { change } \\
\left({ }^{\circ} \mathrm{C}\right)\end{array}$ & $\begin{array}{r}\text { Ocean } \\
\text { temperature } \\
\text { change } \\
\left({ }^{\circ} \mathrm{C}\right)\end{array}$ & $\begin{array}{r}\text { Sea } \\
\text { level } \\
\text { contribution } \\
\text { (cm s.l.e.) }\end{array}$ \\
\hline $\mathrm{RCP} 2.6$ & & & & & & \\
\hline CanESM2 & 4.0 & 2.6 & 7.8 & 3.5 & 2.7 & 16.3 \\
\hline CCSM4 & 2.6 & 1.3 & 4.1 & - & - & - \\
\hline CSIRO Mk3 6 & 1.2 & 1.2 & 1.4 & - & - & - \\
\hline GFDL ESM2G & 0.3 & 0.6 & 2.8 & - & - & - \\
\hline GISS E2 R & 0.1 & 0.8 & 1.9 & 1.7 & 1.2 & 3.4 \\
\hline HadGEM2 ES & 4.7 & 1.0 & 4.4 & 3.6 & 1.3 & 11.1 \\
\hline IPSL CM5A LR & 2.9 & 0.8 & 4.7 & 4.3 & 1.0 & 7.2 \\
\hline MIROC5 & 1.0 & 0.5 & 5.0 & - & - & - \\
\hline MPI ESM LR & 0.9 & 1.0 & 4.4 & -0.2 & 0.5 & 6.0 \\
\hline NorESM1 M & 3.3 & 1.4 & 5.0 & - & - & - \\
\hline Model mean & 2.10 & 1.12 & 4.23 & 2.59 & 1.32 & 8.82 \\
\hline $\begin{array}{l}\text { rms deviation } \\
\text { RCP4.5 }\end{array}$ & \pm 1.53 & \pm 0.57 & \pm 1.80 & \pm 1.62 & \pm 0.73 & \pm 4.48 \\
\hline CanESM2 & 6.1 & 3.3 & 9.3 & 6.8 & 5.3 & 32.0 \\
\hline CCSM4 & 3.5 & 1.5 & 4.5 & - & - & - \\
\hline CSIRO Mk3 6 & 0.6 & 1.7 & 2.8 & 4.8 & 3.1 & 14.4 \\
\hline GFDL ESM2G & 1.8 & 0.9 & 4.2 & - & - & - \\
\hline GISS E2 R & 2.3 & 1.0 & 3.3 & 2.6 & 1.3 & 6.7 \\
\hline HadGEM2 ES & 6.2 & 1.5 & 7.0 & 7.8 & 2.5 & 26.9 \\
\hline IPSL CM5A LR & 5.1 & 1.2 & 5.7 & 5.7 & 1.8 & 19.4 \\
\hline MIROC5 & 4.4 & 1.4 & 6.5 & - & - & - \\
\hline MPI ESM LR & 1.4 & 1.6 & 5.0 & 3.8 & 2.5 & 15.6 \\
\hline NorESM1 M & 4.1 & 1.8 & 6.7 & 5.4 & 2.7 & 25.7 \\
\hline Model mean & 3.56 & 1.62 & 5.50 & 5.27 & 2.77 & 20.11 \\
\hline $\begin{array}{l}\text { rms deviation } \\
\text { RCP6.0 }\end{array}$ & \pm 1.86 & \pm 0.67 & \pm 1.86 & \pm 1.62 & \pm 1.18 & \pm 8.03 \\
\hline CanESM2 & - & - & - & - & - & - \\
\hline CCSM4 & 5.2 & 1.7 & 5.8 & - & - & - \\
\hline CSIRO Mk3 6 & 1.2 & 1.5 & 2.7 & - & - & - \\
\hline GFDL ESM2G & 2.7 & 1.2 & 4.3 & - & - & - \\
\hline GISS E2 R & 2.5 & 1.1 & 3.8 & - & - & - \\
\hline HadGEM2 ES & 6.3 & 1.7 & 6.9 & - & - & - \\
\hline IPSL CM5A LR & 5.0 & 1.2 & 6.4 & - & - & - \\
\hline MIROC5 & 4.4 & 1.3 & 6.3 & - & - & - \\
\hline MPI ESM LR & - & - & - & - & - & - \\
\hline NorESM1 M & 4.7 & 1.7 & 7.1 & - & - & - \\
\hline Model mean & 4.00 & 1.43 & 5.40 & - & - & - \\
\hline rms deviation & \pm 1.59 & \pm 0.22 & \pm 1.49 & - & - & - \\
\hline
\end{tabular}


Table B1. Continued.

\begin{tabular}{|c|c|c|c|c|c|c|}
\hline \multirow[b]{2}{*}{$\begin{array}{l}\text { Climate } \\
\text { scenario } \\
\text { and model }\end{array}$} & \multicolumn{3}{|c|}{2100} & \multicolumn{3}{|c|}{2300} \\
\hline & $\begin{array}{r}\text { Air } \\
\text { temperature } \\
\text { change }\end{array}$ & $\begin{array}{r}\text { Ocean } \\
\text { temperature } \\
\text { change }\end{array}$ & $\begin{array}{r}\text { Sea } \\
\text { level } \\
\text { contribution }\end{array}$ & $\begin{array}{r}\text { Air } \\
\text { temperature } \\
\text { change }\end{array}$ & $\begin{array}{r}\text { Ocean } \\
\text { temperature } \\
\text { change }\end{array}$ & $\begin{array}{r}\text { Sea } \\
\text { level } \\
\text { contribution }\end{array}$ \\
\hline & $\left({ }^{\circ} \mathrm{C}\right)$ & $\left({ }^{\circ} \mathrm{C}\right)$ & (cm s.l.e.) & $\left({ }^{\circ} \mathrm{C}\right)$ & $\left({ }^{\circ} \mathrm{C}\right)$ & (cm s.l.e.) \\
\hline \multicolumn{7}{|l|}{ RCP8.5 } \\
\hline CanESM2 & 8.6 & 5.0 & 16.6 & - & - & - \\
\hline CCSM4 & 6.7 & 2.0 & 8.7 & - & - & - \\
\hline CSIRO Mk3 6 & 5.9 & 2.9 & 6.8 & - & - & - \\
\hline GFDL ESM2G & 6.1 & 2.1 & 7.1 & - & - & - \\
\hline GISS E2 R & 4.1 & 1.1 & 5.1 & - & - & - \\
\hline HadGEM2 ES & 11.1 & 2.9 & 11.7 & - & - & - \\
\hline IPSL CM5A LR & 7.8 & 2.7 & 11.2 & - & - & - \\
\hline MIROC5 & 9.4 & 2.8 & 13.0 & - & - & - \\
\hline MPI ESM LR & 5.3 & 2.7 & 9.1 & - & - & - \\
\hline NorESM1 M & 6.5 & 2.3 & 11.9 & - & - & - \\
\hline Model mean & 7.15 & 2.68 & 10.15 & - & - & - \\
\hline rms deviation & \pm 1.98 & \pm 0.94 & \pm 3.25 & - & - & - \\
\hline
\end{tabular}


Acknowledgements. We thank the two anonymous reviewers for their constructive comments that helped to improve the clarity of this paper. This research received funding from the ice2sea programme from the European Union's 7th Framework Programme grant number 226375. Additional funding came from the Belgian Federal Science Policy Office within its Research Programme on Science for a Sustainable Development under contract SD/CS/06A (iCLIPS). We thank R. Bales for providing the precipitation data set and E. Hanna for the ECMWF data on our model grid. We also acknowledge the World Climate Research Programme's Working Group on Coupled Modelling, responsible for CMIP, and thank the climate modelling groups for producing and making available their model output. This publication is ice2sea contribution no. 132.

Edited by: H. Gudmundsson

\section{References}

Andersen, K., Azuma, N., Barnola, J., Bigler, M., Caillon, P. B. N., Chappellaz, J., Clausen, H., Dahl-Jensen, D., Fischer, H., Flückiger, J., Fritzsche, D., Fujii, Y., Goto-Azuma, K., Grønvold, K., Gundestrup, N., Hansson, M., Huber, C., Hvidberg, C., Johnsen, S., Jonsell, U., Jouzel, J., Kipfstuhl, S., Landais, A., Leuenberger, M., Lorrain, R., Masson-Delmotte, V., Miller, H., Motoyama, H., Narita, H., Popp, T., Rasmussen, S., Raynaud, D., Rothlisberger, R., Ruth, U., Samyn, D., Schwander, J., Shoji, H., Siggard-Andersen, M., Steffensen, J., Stocker, T., Sveinbjörnsðóttir, A., Svensson, A., Takata, M., Tison, J., Thorsteinsson, T., Watanabe, O., Wilhelms, F., White, J., and North Greenland Ice Core Project: High-resolution record of Northern Hemisphere climate extending into the last interglacial period, Nature, 431, 147-151, doi:10.1038/nature02805, 2004.

Andrews, L. C., Catania, G. A., Hoffman, M. J., Gulley, J. D., Luthi, M. P., Ryser, C., Hawley, R. L., and Neumann, T. A.: Direct observations of evolving subglacial drainage beneath the Greenland Ice Sheet, Nature, 514, 80-83, doi:10.1038/nature13796, 2014.

Applegate, P. J., Kirchner, N., Stone, E. J., Keller, K., and Greve, R.: An assessment of key model parametric uncertainties in projections of Greenland Ice Sheet behavior, The Cryosphere, 6, 589606, doi:10.5194/tc-6-589-2012, 2012.

Bales, R., Guo, Q., Shen, D., McConnell, J., Du, G., Burkhart, J., Spikes, V., Hanna, E., and Cappelen, J.: Annual accumulation for Greenland updated using ice core data developed during 20002006 and analysis of daily coastal meteorological data, J. Geophys. Res., 114, D06116, doi:10.1029/2008JD011208, 2009.

Bamber, J. L., Griggs, J. A., Hurkmans, R. T. W. L., Dowdeswell, J. A., Gogineni, S. P., Howat, I., Mouginot, J., Paden, J., Palmer, S., Rignot, E., and Steinhage, D.: A new bed elevation dataset for Greenland, The Cryosphere, 7, 499-510, doi:10.5194/tc-7499-2013, 2013.

Barker, S., Knorr, G., Edwards, R., Parrenin, F., Putnam, A., Skinner, L., Wolff, E., and Ziegler, M.: 800000 years of abrupt climate variability, Science, 334, 347-351, doi:10.1126/science.1203580, 2011.

Bartholomew, I., Nienow, P., Mair, D., Hubbard, A., King, M., and Sole, A.: Seasonal evolution of subglacial drainage and accel- eration in a Greenland outlet glacier, Nat. Geosci., 3, 408-411, doi:10.1038/NGEO863, 2010.

Bartholomew, I., Nienow, P., Sole, A., Mair, D., Cowton, T., King, M., and Palmer, S.: Seasonal variations in Greenland Ice Sheet motion: inland extent and behaviour at higher elevations, Earth Planet. Sc. Lett., 307, 271-278, doi:10.1016/j.eps1.2011.04.014, 2011.

Bevan, S. L., Luckman, A. J., and Murray, T.: Glacier dynamics over the last quarter of a century at Helheim, Kangerdlugssuaq and 14 other major Greenland outlet glaciers, The Cryosphere, 6, 923-937, doi:10.5194/tc-6-923-2012, 2012.

Carr, J. R., Vieli, A., and Stokes, C.: Influence of sea ice decline, atmospheric warming, and glacier width on marine-terminating outlet glacier behavior in northwest Greenland at seasonal to interannual timescales, J. Geophys. Res., 118, 1210-1226, doi:10.1002/jgrf.20088, 2013.

Church, J., Clark, P., Cazenave, A., Gregory, J., Jevrejeva, S., Levermann, A., Merrifield, M., Milne, G., Nerem, R., Nunn, P., Payne, A., Pfeffer, W., Stammer, D., and Unnikrishnan, A.: Sea Level Change, in: Climate Change 2013: The Physical Science Basis, Contribution of Working Group I to the Fifth Assessment Report of the Intergovernmental Panel on Climate Change, edited by: Stocker, T. F., Qin, D., Plattner, G.-K., Tignor, M., Allen, S. K., Boschung, J., Nauels, A., Xia, Y., Bex, V., and Midgley, P. M.: Cambridge University Press, Cambridge, United Kingdom and New York, NY, USA, 2013.

Colgan, W., Steffen, K., McLamb, W., Abdalati, W., Rajaram, H., Motyka, R., Phillips, T., and Anderson, R.: An increase in crevasse extent, West Greenland: hydrologic implications, Geophys. Res. Lett., 38, L18502, doi:10.1029/2011GL048491, 2011.

Csatho, B. M., Schenk, A. F., van der Veen, C. J., Babonis, G., Duncan, K., Rezvanbehbahani, S., van den Broeke, M. R., Simonsen, S. B., Nagarajan, S., and van Angelen, J. H.: Laser altimetry reveals complex pattern of Greenland Ice Sheet dynamics, P. Natl. Acad. Sci. USA, 111, 18478-18483, doi:10.1073/pnas.1411680112, 2014.

Dansgaard, W., Johnsen, S., Clausen, H., Dahl-Jensen, D., Gundestrup, N., Hammer, C., Hvidberg, C., Steffensen, J., Sveinbjörnsðóttir, A., Jouzel, J., and Bond, G.: Evidence for general instability of past climate from a 250-kyr ice-core record, Nature, 364, 218-220, doi:10.1038/364218a0, 1993.

Enderlin, E. M., Howat, I. M., Jeong, S., Noh, M.-J., van Angelen, J. H., and van den Broeke, M. R.: An improved mass budget for the Greenland ice sheet, Geophys. Res. Lett., 41, 866-872, doi:10.1002/2013GL059010, 2014.

Ettema, J., van den Broeke, M., van Meijgaard, E., van de Berg, W., Bamber, J., Box, J., and Bales, R.: Higher surface mass balance of the Greenland ice sheet revealed by highresolution climate modeling, Geophys. Res. Lett., 36, L12501, doi:10.1029/2009GL038110, 2009.

Falkner, K., Melling, H., Münchow, A., Box, J., Johnson, H., Gudmandsen, P., Samelson, R., Copland, L., Steffen, K., Rignot, E., and Higgins, A.: Context for the recent massive Petermann Glacier Calving Event, EOS T. Am. Geophys. Un., 92, 117-119, doi:10.1029/2011EO140001, 2011.

Fettweis, X., Tedesco, M., van den Broeke, M., and Ettema, J.: Melting trends over the Greenland ice sheet (1958-2009) from spaceborne microwave data and regional climate models, The Cryosphere, 5, 359-375, doi:10.5194/tc-5-359-2011, 2011. 
Franco, B., Fettweis, X., Lang, C., and Erpicum, M.: Impact of spatial resolution on the modelling of the Greenland ice sheet surface mass balance between 1990-2010, using the regional climate model MAR, The Cryosphere, 6, 695-711, doi:10.5194/tc6-695-2012, 2012.

Fürst, J. J., Rybak, O., Goelzer, H., De Smedt, B., de Groen, P., and Huybrechts, P.: Improved convergence and stability properties in a three-dimensional higher-order ice sheet model, Geosci. Model Dev., 4, 1133-1149, doi:10.5194/gmd-4-1133-2011, 2011.

Fürst, J. J., Goelzer, H., and Huybrechts, P.: Effect of higher-order stress gradients on the centennial mass evolution of the Greenland ice sheet, The Cryosphere, 7, 183-199, doi:10.5194/tc-7183-2013, 2013.

Fyke, J., Eby, M., Mackintosh, A., and Weaver, A.: Impact of climate sensitivity and polar amplification on projections of Greenland Ice Sheet loss, Climate Dynamics, 43, 2249-2260, doi:10.1007/s00382-014-2050-7, 2014.

Gillet-Chaulet, F., Gagliardini, O., Seddik, H., Nodet, M., Durand, G., Ritz, C., Zwinger, T., Greve, R., and Vaughan, D. G.: Greenland ice sheet contribution to sea-level rise from a new-generation ice-sheet model, The Cryosphere, 6, 1561-1576, doi:10.5194/tc-6-1561-2012, 2012.

Goelzer, H., Huybrechts, P., Fürst, J., Nick, F., Andersen, M., Edwards, T., Fettweis, X., Payne, A., and Shannon, S.: Sensitivity of Greenland ice sheet projections to model formulations, J. Glaciol., 59, 733-749, doi:10.3189/2013JoG12J182, 2013.

Graversen, R., Drijfhout, S., van de Wal, R. S. W., Bintanja, R., and Helsen, M.: Greenland's contribution to global sea-level rise by the end of the 21st century, Clim. Dynam., 37, 1427-1442, doi:10.1007/s00382-010-0918-8, 2011.

Gregory, J. and Huybrechts, P.: Ice-sheet contributions to future sea-level change, Philos. T. R. Soc. A, 364, 1709-1731, doi:10.1098/rsta.2006.1796, 2006.

Greve, R., Saito, F., and Abe-Ouchi, A.: Initial results of the SeaRISE numerical experiments with the models SICOPOLIS and IcIES for the Greenland ice sheet, Ann. Glaciol., 52, 23-30, doi:10.3189/172756411797252068, 2011.

Hanna, E., Huybrechts, P., Janssens, I., Cappelen, J., Steffen, K., and Stephens, A.: Runoff and mass balance of the Greenland ice sheet: 1958-2003, J. Geophys. Res., 110, D13108, doi:10.1029/2004JD005641, 2005.

Hanna, E., Huybrechts, P., Cappelen, J., Steffen, K., Bales, R., Burgess, E., McConnell, J., Steffensen, J., van den Broeke, M., Wake, L., Bigg, G., Griffiths, M., and Savas, D.: Greenland ice sheet surface mass balance 1870 to 2010 based on twentieth century reanalysis, and links with global climate forcing, J. Geophys. Res., 116, D24121, doi:10.1029/2011JD016387, 2011.

Hardy, R., Bamber, J., and Orford, S.: The delineation of drainage basins on the Greenland ice sheet for mass-balance analyses using a combined modelling and geographical information system approach, Hydrol. Process., 14, 1931-1941, 2000.

Hindmarsh, R. C. A.: A numerical comparison of approximations to the Stokes equations used in ice sheet and glacier modelling, J. Geophys. Res., 109, F01012, doi:10.1029/2003JF000065, 2004.

Holland, D., Thomas, R., De Young, B., Ribergaard, M., and Lyberth, B.: Acceleration of Jakobshavn Isbræ triggered by warm subsurface ocean waters, Nat. Geosci., 1, 659-664, doi:10.1038/ngeo316, 2008.
Howat, I. and Eddy, A.: Multi-decadal retreat of Greenland's marine-terminating glaciers, J. Glaciol., 57, 389-396, doi:10.3189/002214311796905631, 2011.

Huybrechts, P. and de Wolde, J.: The dynamic response of the Greenland and Antarctic ice sheets to multiple-century climatic warming, J. Climate, 12, 2169-2188, doi:10.1175/15200442(1999)012<2169:TDROTG>2.0.CO;2, 1999.

Huybrechts, P.: Sea-level changes at the LGM from ice-dynamic reconstructions of the Greenland and Antarctic ice sheets during the glacial cycles, Quaternary Sci. Rev., 21, 203-231, doi:10.1016/S0277-3791(01)00082-8, 2002.

Inall, M. E., Murray, T., Cottier, F. R., Scharrer, K., Boyd, T. J., Heywood, K. J., and Bevan, S. L.: Oceanic heat delivery via Kangerdlugssuaq Fjord to the south-east Greenland ice sheet, J. Geophys. Res., 119, 631-645, doi:10.1002/2013JC009295, 2014.

IPCC: Climate Change 2013: The Physical Science Basis. Contribution of Working Group I to the Fifth Assessment Report of the Intergovernmental Panel on Climate Change, Cambridge University Press, Cambridge, UK and New York, NY, USA, doi:10.1017/CBO9781107415324, 2013.

Jackson, R. H., Straneo, F., and Sutherland, D. A.: Externally forced fluctuations in ocean temperature at Greenland glaciers in non-summer months, Nature Geoscience, 7, 503-508, doi:10.1038/ngeo2186, 2014.

Janssens, I. and Huybrechts, P.: The treatment of meltwater retention in mass-balance parameterizations of the Greenland ice sheet, Ann. Glaciol., 31, 133-140, doi:10.3189/172756400781819941, 2000.

Joughin, I., Abdalati, W., and Fahnestock, M.: Large fluctuations in speed on Greenland's Jakobshavn Isbræ glacier, Nature, 432, 608-610, doi:10.1038/nature03130, 2004.

Joughin, I., Das, S., King, M., Smith, B., Howat, I., and Moon, T.: Seasonal speedup along the western flank of the Greenland Ice Sheet, Science, 320, 781-783, doi:10.1126/science.1153288, 2008a.

Joughin, I., Howat, I., Alley, R., Ekstrom, G., Fahnestock, M., Moon, T., Nettles, M., Truffer, M., and Tsai, V.: Ice-front variation and tidewater behavior on Helheim and Kangerdlugssuaq Glaciers, Greenland, J. Geophys. Res., 113, F01004, doi:10.1029/2007JF000837, 2008b.

Joughin, I., Howat, I., Fahnestock, M., Smith, B., Krabill, W., Alley, R., Stern, H., and Truffer, M.: Continued evolution of Jakobshavn Isbrae following its rapid speedup, J. Geophys. Res., 113, F04006, doi:10.1029/2008JF001023, 2008c.

Joughin, I., Smith, B., Howat, I., Scambos, T., and Moon, T.: Greenland flow variability from ice-sheet-wide velocity mapping, J. Glaciol., 56, 415-430, 2010.

Kobashi, T., Kawamura, K., Severinghaus, J., Barnola, J.-M., Nakaegawa, T., Vinther, B., Johnsen, S., and Box, J.: High variability of Greenland surface temperature over the past 4000 years estimated from trapped air in an ice core, Geophys. Res. Lett., 38, L21501, doi:10.1029/2011GL049444, 2011.

Lipscomb, W. H., Fyke, J. G., Vizcaíno, M., Sacks, W. J., Wolfe, J., Vertenstein, M., Craig, A., Kluzek, E., and Lawrence, D. M.: Implementation and Initial Evaluation of the Glimmer Community Ice Sheet Model in the Community Earth System Model, J. Climate, 26, 7352-7371, doi:10.1175/JCLI-D-12-00557.1, 2013.

McKay, M., Beckman, R., and Conover, W.: A comparison of three methods for selecting values of input variable in the analysis 
of output from a computer code, Technometrics, 21, 239-245, doi: $10.2307 / 1268522,1979$.

Meehl, G., Stocker, T., Collins, W., Friedlingstein, P., Gaye, A., Gregory, J., Kitoh, A., Knutti, R., Murphy, J., Noda, A., Raper, S., Watterson, I., Weaver, A., and Zhao, Z.: Global Climate Projections. in: Climate Change 2007: The Physical Science Basis. Contribution of Working Group I to the Fourth Assessment Report of the Intergovernmental Panel on Climate Change, Cambridge University Press, Cambridge, UK and New York, NY, USA, 747-846, 2007.

Moon, T., and Joughin, I.: Changes in ice front position on Greenland's outlet glaciers from 1992 to 2007, J. Geophys. Res., 113, F02022, doi:10.1029/2007JF000927, 2008.

Moon, T., Joughin, I., Smith, B., and Howat, I.: 21st-century evolution of Greenland outlet glacier velocities, Science, 336, 576578, doi:10.1126/science.1219985, 2012.

Moon, T., Joughin, I., Smith, B., van den Broeke, M. R., van de Berg, W. J., Noël, B., and Usher, M.: Distinct patterns of seasonal Greenland glacier velocity, Geophys. Res. Lett., 41, 7209-7216, doi:10.1002/2014GL061836, 2014.

Moss, R., Edmonds, J., Hibbard, K., Manning, M., Rose, S., van Vuuren, D., Carter, T., Emori, S., Kainuma, M., Kram, T., Meehl, G., Mitchell, J., Nakicenovic, N., Riahi, K., Smith, S., Stouffer, R., Thomson, A., Weyant, J., and Wilbanks, T.: The next generation of scenarios for climate change research and assessment, Nature, 463, 747-756, doi:10.1038/nature08823, 2010.

Motyka, R., Truffer, M., Fahnestock, M., Mortensen, J., Rysgaard, S., and Howat, I.: Submarine melting of the 1985 Jakobshavn Isbræ floating tongue and the triggering of the current retreat, J. Geophys. Res., 116, F01007, doi:10.1029/2009JF001632, 2011.

Münchow, A., Falkner, K., Melling, H., Rabe, B., and Johnson, H.: Ocean warming of nares strait bottom waters off northwest Greenland, 2003-2009, Oceanography, 24, 114-123, doi:10.5670/oceanog.2011.62, 2011.

Murray, T., Scharrer, K., James, T., Dye, S., Hanna, E., Booth, A., Selmes, N., Luckman, A., Hughes, A., Cook, S., and Huybrechts, P.: Ocean regulation hypothesis for glacier dynamics in southeast Greenland and implications for ice sheet mass changes, J. Geophys. Res., 115, F03026, doi:10.1029/2009JF001522, 2010.

Nick, F., Vieli, A., Howat, I., and Joughin, I.: Large-scale changes in Greenland outlet glacier dynamics triggered at the terminus, Nat. Geosci., 2, 110-114, doi:10.1038/NGEO394, 2009.

Nick, F., Luckman, A., Vieli, A., van der Veen, C., Van As, D., van de Wal, R. S. W., Pattyn, F., Hubbard, A., and Floricioiu, D.: The response of Petermann Glacier, Greenland, to large calving events, and its future stability in the context of atmospheric and oceanic warming, J. Glaciol., 58, 229-239, doi:10.3189/2012JoG11J242, 2012.

Nick, F., Vieli, A., Andersen, M., Joughin, I., Payne, A., Edwards, T., Pattyn, F., and van de Wal, R. S. W.: Future sea level rise from Greenland's major outlet glaciers in a warming climate, Nature, 497, 235-238, doi:10.1038/nature12068, 2013.

Pattyn, F.: Antarctic subglacial conditions inferred from a hybrid ice sheet/ice stream model, Earth Planet. Sc. Lett., 295, 451-461, doi:10.1016/j.epsl.2010.04.025, 2010 .

Perego, M., S. Price, and G. Stadler (2014), Optimal initial conditions for coupling ice sheet models to Earth system mod- els, Journal of Geophysical Research, 119(9), 1894-1917, doi:10.1002/2014JF003181, 2014.

Pfeffer, W., Harper, J., and O'Neel, S.: Kinematic constraints on glacier contributions to 21st-century sea-level rise, Science, 321, 1340-1343, doi:10.1126/science.1159099, 2008.

Quiquet, A., Punge, H. J., Ritz, C., Fettweis, X., Gallée, H., Kageyama, M., Krinner, G., Salas y Mélia, D., and Sjolte, J.: Sensitivity of a Greenland ice sheet model to atmospheric forcing fields, The Cryosphere, 6, 999-1018, doi:10.5194/tc-6-9992012, 2012.

Rahmstorf, S.: A semi-empirical approach to projecting future sealevel rise, Science, 315, 368-370, doi:10.1126/science.1135456, 2007.

Rignot, E., and Kanagaratnam, P.: Changes in the velocity structure of the Greenland ice sheet, Science, 311, 986-990, doi:10.1126/science.1121381, 2006.

Rignot, E., Koppes, M., and Velicogna, I.: Rapid submarine melting of the calving faces of West Greenland glaciers, Nat. Geosci., 3, 187-191, doi:10.1038/NGEO765, 2010.

Rignot, E., Velicogna, I., van den Broeke, M., Monaghan, A., and Lenaerts, J.: Acceleration of the contribution of the Greenland and Antarctic ice sheets to sea level rise, Geophys. Res. Lett., 38, L05503, doi:10.1029/2011GL046583, 2011.

Robinson, A., Calov, R., and Ganopolski, A.: Greenland ice sheet model parameters constrained using simulations of the Eemian Interglacial, Clim. Past, 7, 381-396, doi:10.5194/cp-7-381-2011, 2011.

Sasgen, I., van den Broeke, M., Bamber, J., Rignot, E., Sørensen, L., Wouters, B., Martinec, Z., Velicogna, I., and Simonsen, S.: Timing and origin of recent regional ice-mass loss in Greenland, Earth Planet. Sc. Lett., 333-334, 293-303, doi:10.1016/j.epsl.2012.03.033, 2012.

Schoof, C.: Ice-sheet acceleration driven by melt supply variability, Nature, 468, 803-806, doi:10.1038/nature09618, 2010.

Shannon, S., Payne, A., Bartholomew, I., van den Broeke, M., Edwards, T., Fettweis, X., Gagliardinid, O., Gillet-Chaulet, F., Goelzer, H., Hoffman, M., Huybrechts, P., Mair, D., Nienow, P., Perego, M., Price, S., Smeets, C., Sole, A., van de Wal, R. S. W., and Zwinger, T.: Enhanced basal lubrication and the contribution of the Greenland ice sheet to future sea level rise, P. Natl. Acad. Sci. USA, 110, 14156-14161, doi:10.1073/pnas.1212647110, 2013.

Shapiro, N., and Ritzwoller, M.: Inferring surface heat flux distributions guided by a global seismic model: particular application to Antarctica, Earth Planet. Sc. Lett., 223, 213-224, doi:10.1016/j.epsl.2004.04.011, 2004.

Shepherd, A., Hubbard, A., Nienow, P., King, M., McMillan, M., and Joughin, I.: Greenland ice sheet motion coupled with daily melting in late summer, Geophys. Res. Lett., 36, L01501, doi:10.1029/2008GL035758, 2009.

Shepherd, A., Ivins, E., Geruo, A., Barletta, V., Bentley, M., Bettadpur, S., Briggs, K., Bromwich, D., Forsberg, R., Galin, N., Horwath, M., Jacobs, S., Joughin, I., King, M., Lenaerts, J., Li, J., Ligtenberg, S., Luckman, A., Luthcke, S., McMillan, M., Meister, R., Milne, G., Mouginot, J., Muir, A., Nicolas, J., Paden, J., Payne, A., Pritchard, H., Rignot, E., Rott, H., Sørensen, L., Scambos, T., Scheuchl, B., Schrama, E., Smith, B., Sundal, A., van Angelen, J., van de Berg, W., van den Broeke, M., Vaughan, D. G., Velicogna, I., Wahr, J., Whitehouse, P., Wing- 
ham, D., Yi, D., Young, D., and Zwally, H.: A reconciled estimate of ice-sheet mass balance, Science, 338, 1183-1189, doi:10.1126/science.1228102, 2012.

Simpson, M., Milne, G., Huybrechts, P., and Long, A.: Calibrating a glaciological model of the Greenland ice sheet from the Last Glacial Maximum to present-day using field observations of relative sea level and ice extent, Quaternary Sci. Rev., 28, 16311657, doi:10.1016/j.quascirev.2009.03.004, 2009.

Stearns, L., and Hamilton, G.: Rapid volume loss from two East Greenland outlet glaciers quantified using repeat stereo satellite imagery, Geophys. Res. Lett., 34, L05503, doi:10.1029/2006GL028982, 2007.

Stone, E. J., Lunt, D. J., Rutt, I. C., and Hanna, E.: Investigating the sensitivity of numerical model simulations of the modern state of the Greenland ice-sheet and its future response to climate change, The Cryosphere, 4, 397-417, doi:10.5194/tc-4-397-2010, 2010.

Straneo, F., Hamilton, G., Sutherland, D., Stearns, L., Davidson, F., Hammill, M., Stenson, G., and Rosing-Asvid, A.: Rapid circulation of warm subtropical waters in a major glacial fjord in East Greenland, Nat. Geosci., 3, 182-186, doi:10.1038/NGEO764, 2010.

Straneo, F., Curry, R., Sutherland, D., Hamilton, G., Cenedese, C., Våge, K., and Stearns, L.: Impact of fjord dynamics and glacial runoff on the circulation near Helheim Glacier, Nat. Geosci., 4, 322-327, doi:10.1038/NGEO1109, 2011.

Straneo, F., Sutherland, D., Holland, D., Gladish, C., Hamilton, G., Johnson, H., Rignot, E., Xu, Y., and Koppes, M.: Characteristics of ocean waters reaching Greenland's glaciers, Ann. Glaciol., 53, 202-210, doi:10.3189/2012AoG60A059, 2012.

Straneo, F., and Heimbach, P.: North Atlantic warming and the retreat of Greenland's outlet glaciers, Nature, 504, 36-43, doi:10.1038/nature12854, 2013.

Sundal, A., Shepherd, A., Nienow, P., Hanna, E., Palmer, S., and Huybrechts, P.: Melt-induced speed-up of Greenland ice sheet offset by efficient subglacial drainage, Nature, 469, 521-524, doi:10.1038/nature09740, 2011.

Taylor, K., Stouffer, R., and Meehl, G.: An overview of CMIP5 and the experiment design, B. Am. Meteorol. Soc., 93, 485-498, doi:10.1175/BAMS-D-11-00094.1, 2012.

Tedstone, A. J., Nienow, P. W., Gourmelen, N., and Sole, A. J.: Greenland ice sheet annual motion insensitive to spatial variations in subglacial hydraulic structure, Geophys. Res. Lett., 41, 8910-8917, doi:10.1002/2014GL062386, 2014. van de Wal, R. S. W., Boot, W., van den Broeke, M., Smeets, C., Reijmer, C., Donker, J., and Oerlemans, J.: Large and rapid meltinduced velocity changes in the ablation zone of the Greenland Ice Sheet, Science, 321, 111-113, doi:10.1126/science.1158540, 2008.

van den Broeke, M., Bamber, J., Ettema, J., Rignot, E., Schrama, E., van de Berg, J., van Meijgaard, E., Velicogna, I., and Wouters, B.: Partitioning recent Greenland mass loss, Science, 326, 984-986, doi:10.1126/science.1178176, 2009.

van den Broeke, M. R., Smeets, C. J. P. P., and van de Wal, R. S. W.: The seasonal cycle and interannual variability of surface energy balance and melt in the ablation zone of the west Greenland ice sheet, The Cryosphere, 5, 377-390, doi:10.5194/tc-5-377-2011, 2011.

van der Veen, C., Plummer, J., and Stearns, L.: Controls on the recent speed-up of Jakobshavn Isbrae, West Greenland, J. Glaciol., 57, 770-782, doi:10.3189/002214311797409776, 2011.

Vaughan, D. G., Comiso, J., Allison, I., Carrasco, J., Kaser, G., Kwok, R., Mote, P., Murray, T., Paul, F., Ren, J., Rignot, E., Solomina, O., and Zhang, T.: Observations: Cryosphere. in: Climate Change 2013: The Physical Science Basis. Contribution of Working Group I to the Fifth Assessment Report of the Intergovernmental Panel on Climate Change, Cambridge University Press, Cambridge, UK and New York, NY, USA, 316-382, 2013.

Vernon, C. L., Bamber, J. L., Box, J. E., van den Broeke, M. R., Fettweis, X., Hanna, E., and Huybrechts, P.: Surface mass balance model intercomparison for the Greenland ice sheet, The Cryosphere, 7, 599-614, doi:10.5194/tc-7-599-2013, 2013.

Yoshimori, M., and Abe-Ouchi, A.: Sources of Spread in Multimodel Projections of the Greenland Ice Sheet Surface Mass Balance, J. Climate, 25, 1157-1175, doi:10.1175/2011JCLI4011.1, 2011.

Zwally, H., Abdalati, W., Herring, T., Larson, K., Saba, J., and Steffen, K.: Surface melt-induced acceleration of Greenland ice-sheet flow, Science, 297, 218-222, doi:10.1126/science.1072708, 2002.

Zwally, H., Li, J., Brenner, A., Beckley, M., Cornejo, H., Dimarzio, J., Giovinetto, M., Neumann, T., Robbins, J., Saba, J., Yi, D., and Wang, W.: Greenland ice sheet mass balance: distribution of increased mass loss with climate warming; 2003-07 versus 1992-2002, J. Glaciol., 57, 88-102, doi:10.3189/002214311795306682, 2011. 